\title{
Spatial and Temporal Changes in PD-L1 Expression in Cancer: The Role of Genetic Drivers, Tumor Microenvironment and Resistance to Therapy
}

\author{
Elena Shklovskaya * and Helen Rizos \\ Department of Biomedical Sciences, Faculty of Medicine, Health and Human Sciences, Macquarie University, \\ Sydney 2109, Australia; helen.rizos@mq.edu.au \\ * Correspondence: elena.shklovskaya@mq.edu.au
}

Received: 16 August 2020; Accepted: 24 September 2020; Published: 27 September 2020

\begin{abstract}
Immunotherapies blocking immune inhibitory receptors programmed cell death-1 (PD-1) and cytotoxic T-lymphocyte-associated protein-4 (CTLA-4) on T-cells have dramatically improved patient outcomes in a range of advanced cancers. However, the lack of response, and the development of resistance remain major obstacles to long-term improvements in patient outcomes. There is significant interest in the clinical use of biomarkers to improve patient selection, and the expression of PD-1 ligand 1 (PD-L1) is often reported as a potential biomarker of response. However, accumulating evidence suggests that the predictive value of PD-L1 expression in tumor biopsies is relatively low due, in part, to its complex biology. In this review, we discuss the biological consequences of PD-L1 expression by various cell types within the tumor microenvironment, and the complex mechanisms that regulate PD-L1 expression at the genomic, transcriptomic and proteomic levels.
\end{abstract}

Keywords: immune checkpoint blockade; immunotherapy response biomarker; PD-L1 immune checkpoint; PD-L1 regulation; tumor microenvironment

\section{Introduction}

Therapeutic antibodies that block the programmed cell death-1 (PD-1) immune inhibitory receptor or its ligand PD-L1 (CD274, B7-H1) have produced remarkable improvements in many patients with advanced malignancies. The clinical efficacy of PD-1 blockade was initially demonstrated in melanoma, renal, bladder and lung cancers and Hodgkin's disease [1-5]. Currently, several therapeutic antibodies blocking either PD-1 (nivolumab, pembrolizumab, cemiplimab) or PD-L1 (atezolizumab, durvalumab, avelumab) have been FDA-approved for multiple indications, and additional antibodies directed at these inhibitory checkpoints have entered clinical trials.

PD-L1 expression in tumor biopsies has emerged as an important biomarker of response to immune checkpoint blockade directed at the PD-1 axis. Four diagnostic companion PD-L1 immunohistochemistry tests have been approved for use with PD-1/PD-L1 blocking antibodies in selected cancer subtypes (Dako platform 22C3, 28-8 and Ventana platform SP263, SP142) [6]. Despite a good concordance between these tests [6], PD-L1 expression remains an imperfect biomarker of response to PD-1 blocking immunotherapies, as many patients with PD-L1 expression in the tumor do not respond to treatment while a subset of patients with PD-L1-negative tumors will respond to PD-1 blockade [7,8]. These observations emphasize the need to better understand PD-L1 biology. Several recent studies have provided new insights into the complexity of PD-1/PD-L1 regulatory networks within the tumor microenvironment. In this review, we will discuss some of these recent findings in the context of PD-L1 expression within the tumor microenvironment, and changes in PD-L1 expression during tumor evolution. 


\section{The Significance of PD-L1 Expression on Tumor and Non-Tumor Cells}

A classification based on tumor PD-L1 expression and the presence of tumor-infiltrating T-cells (TILs) has initially been developed for melanoma, to help select patients likely to respond to immunotherapies [7,9-11] (Figure 1). Melanoma tumors can be classified as (i) PD-L1-positive, TIL-positive ("hot" tumors, 35\%), (ii) PD-L1-negative, TIL-negative ("cold" tumors, 40\%), (iii) PD-L1-negative, TIL-positive (20\%) or (iv) PD-L1-positive, TIL-negative (5\%) tumors [11,12]. These subgroups are not consistently defined across tumor types however, and do not provide the predictive accuracy necessary for routine clinical management. In addition, different methods of staining and scoring, such as the use of different positivity thresholds, have contributed to variable conclusions regarding the role of tumor PD-L1 expression as a biomarker predictive of response to anti-PD-1-based therapies.

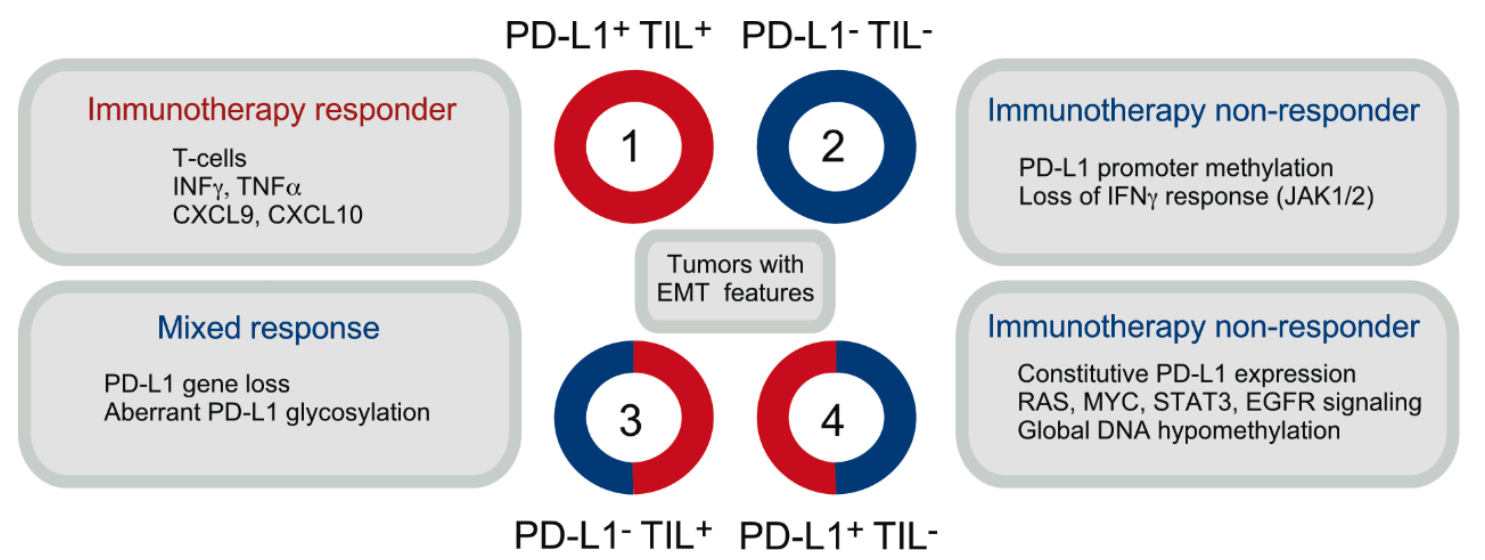

Figure 1. Classification of melanoma tumors based on the degree of T-cell infiltration (TIL) and PD-L1 expression. Categories are aligned with the dominant patient response and mechanisms responsible for high or low/absent PD-L1 expression. Note that tumors with epithelial-to-mesenchymal transition (EMT) features can be found in any of the four groups.

PD-L1 expression on non-cancer cells has also been shown to have predictive value in several cancers [13]. For instance, high expression of PD-L1 on immune cells infiltrating the tumor was shown to be an independent predictor of better melanoma patient outcomes following tumor resection [14], and a better predictor of response to PD-1 blockade than PD-L1 expression on tumor cells in immunogenic cancers such as melanoma, non-small cell lung cancer and urothelial cancer $[3,4,15]$. Expression of PD-L1 on non-tumoral cells in the tumor microenvironment can occur in the absence or presence of PD-L1 expression on tumor cells, and expression on both types can play a role in immune-mediated tumor control. Elegant animal studies by Arlene Sharpe's group demonstrated that both tumor- and host-derived PD-L1 can restrict anti-tumor immunity and their relative contributions may relate to the level of tumor immunogenicity. For instance, PD-L1 expression on immunogenic MC38 colorectal tumor cells directly suppressed CD8 T-cell cytotoxicity and was dominant in suppressing anti-tumor immunity [16]. In contrast, PD-L1 expression on non-tumor cells was required for the immune evasion of the poorly immunogenic Braf/Pten-mutant melanoma [16]. Importantly, differences in the expression level of PD-L1 within the tumor microenvironment did not account for the distinct contributions of tumor- versus host-derived PD-L1 in modulating anti-tumor immune responses [16].

\section{PD-L1 Expression on Non-Tumor Cells}

Within the solid tumor microenvironment, PD-L1 can be expressed on many cells of hematopoietic origin, often collectively referred to as "immune infiltrate", including dendritic cells [17], tumor-associated macrophages (TAMs) [4,18], myeloid-derived suppressor cells (MDSCs) [19] and T-cells [3]. PD-L1 can also be expressed on the non-hematopoietic stromal elements, principally the endothelial cells of the tumor vasculature [20] and cancer-associated fibroblasts [21]. Expression 
of PD-L1 by these diverse stromal elements has both overlapping and non-redundant roles in immune-mediated tumor control, particularly in the context of therapies targeting the PD-1/PD-L1 inhibitory axis [3,4].

Dendritic cells (DCs). Tumor-associated DCs upregulate PD-L1 mainly in response to interferon- $\gamma$ (IFN $\gamma$ ) released by tumor-infiltrating T-cells. Since activated T-cells in the tumor bed represent the principal local source of IFN $\gamma$, PD-L1 expression by DCs and other myeloid cells can be regarded as a surrogate of T-cell activation resulting from tumor antigen recognition [22,23]. Type I IFNs can also upregulate PD-L1 on myeloid cells, augmenting cytotoxic T-cell responses via improved antigen presentation, thus enhancing the likelihood of clinical response to PD-1 blockade [24].

PD-L1 expressed on DCs provides a direct T-cell inhibitory input via PD-1 but also helps override T-cell activation in the context of antigen recognition [17,25]. PD-L1 has two binding partners, the inhibitory receptor PD-1 on T-cells and the co-stimulatory molecule CD80 (B7.1) on antigen-presenting cells. In the tumor microenvironment, DCs express both PD-L1 and CD80, with the amount of PD-L1 greatly exceeding that of CD80. During the DC-T-cell cross-talk, PD-L1 on the DC binds to and sequesters CD80 in cis, while the excess of unbound PD-L1 interacts with PD-1 on the T-cell, resulting in functional inactivation. Anti-PD-L1 antibodies release CD80 from this sequestered form and re-instate the CD80-CD28 co-stimulatory interaction while simultaneously blocking the PD-L1-PD-1 inhibitory pathway, resulting in augmented T-cell activation upon antigen recognition [17] (Figure 2). Of note, the inability of PD-L1 to bind CD80 in cis resulted in attenuated immune responses, including anti-tumor responses [25].

T-cells. Tumor antigen-specific T-cells within the tumor microenvironment often express multiple inhibitory receptors including PD-1 and this expression profile is indicative of T-cell inactivation, also termed exhaustion or dysfunction [26]. However, T-cells also express PD-L1, which is rapidly upregulated following T-cell activation and is important for T-cell survival [27]. PD-L1-deficient T-cells are more susceptible to killing by cytotoxic T-cells, indicating that PD-L1 protects T-cells undergoing clonal expansion and supports optimal protective immunity [27]. PD-L1-deficient T-cells exhibit enhanced rates of apoptosis, reduced metabolism, diminished production of inflammatory cytokines and abnormal expression of tissue-homing receptors both at baseline and after activation [28].

The ligation of PD-L1 expressed by T-cells can promote tumor immune escape via diverse mechanisms [29]. First, T-cell-expressed PD-L1 can engage with PD-1 expressed on macrophages to promote M2 polarization. Second, PD-L1 on T-cells can engage with PD-1 expressed on other T-cells to reduce production of effector cytokines IFN $\gamma$ and tumor necrosis factor (TNF) $\alpha$. Third, T-cell-expressed PD-L1 can function as a receptor in T-cells. This so-called "back-signaling" can promote T-helper 1 (Th1)-to-Th17 switch in CD4 T-cells [29], a non-responsive (anergic) phenotype in CD8 T-cells [29] and apoptosis in activated T-cells [30]; the ligation of PD-L1 on T-cells was as efficient as PD-1 ligation in suppressing T-cell functionality [29]. In addition to PD-1 and PD-L1, activated T-cells can also express CD80 known to restrain T-cell effector function through CTLA-4 [31]; the role for PD-L1-CD80 interactions in T-cell bidirectional signaling remains to be addressed. In summary, T-cell-expressed PD-L1 contributes to the accumulation of dysfunctional T-cells in the tumor, via enhanced clonal survival coupled with reduced effector functions. Targeting T-cell-expressed PD-L1 offers new therapeutic opportunities, in particular for T-cell-infiltrated cancers with low/absent PD-L1 expression on tumor cells.

Tumor-associated macrophages (TAMs). Generally, a high density of myeloid cells in the tumor correlates with reduced T-cell infiltration and a poor prognosis (reviewed in [32]). Myeloid precursors are recruited to tumors in a T-cell-independent manner, and the regulation of PD-L1 expression in myeloid cells, particularly in the immunologically "cold" tumors, does not necessarily reflect a concurrent T-cell response [33]. Hypoxia and the accompanying angiogenesis-promoting angiopoietins recruit monocytes expressing the cognate TIE2 receptor to tumors, where these myeloid precursors preferentially migrate to the hypoxic areas and differentiate into TAMs [34-36]. Accordingly, hypoxia is an important regulator of TAM biology [37]. PD-L1 expression in myeloid cells is upregulated directly by the hypoxia-inducible factor (HIF)- $1 \alpha$ that binds to the PD-L1 promoter to induce PD-L1 
transcription [38]. Furthermore, TAMs upregulate PD-L1 expression by assuming aerobic glycolysis [39] while also secreting TNF $\alpha$ that promotes aerobic glycolysis in cancer cells [40] and augments PD-L1 expression on myeloid cells [41]. Sustained chronic inflammation enhances PD-L1 expression on myeloid cells through the cyclooxygenase 2/prostaglandin E2 pathway [19] and interleukin (IL)-6 production [42]. Type I and type II interferons augment PD-L1 expression on myeloid cells in the context of immunotherapies that activate innate or adaptive anti-cancer immune responses, respectively [43-45].

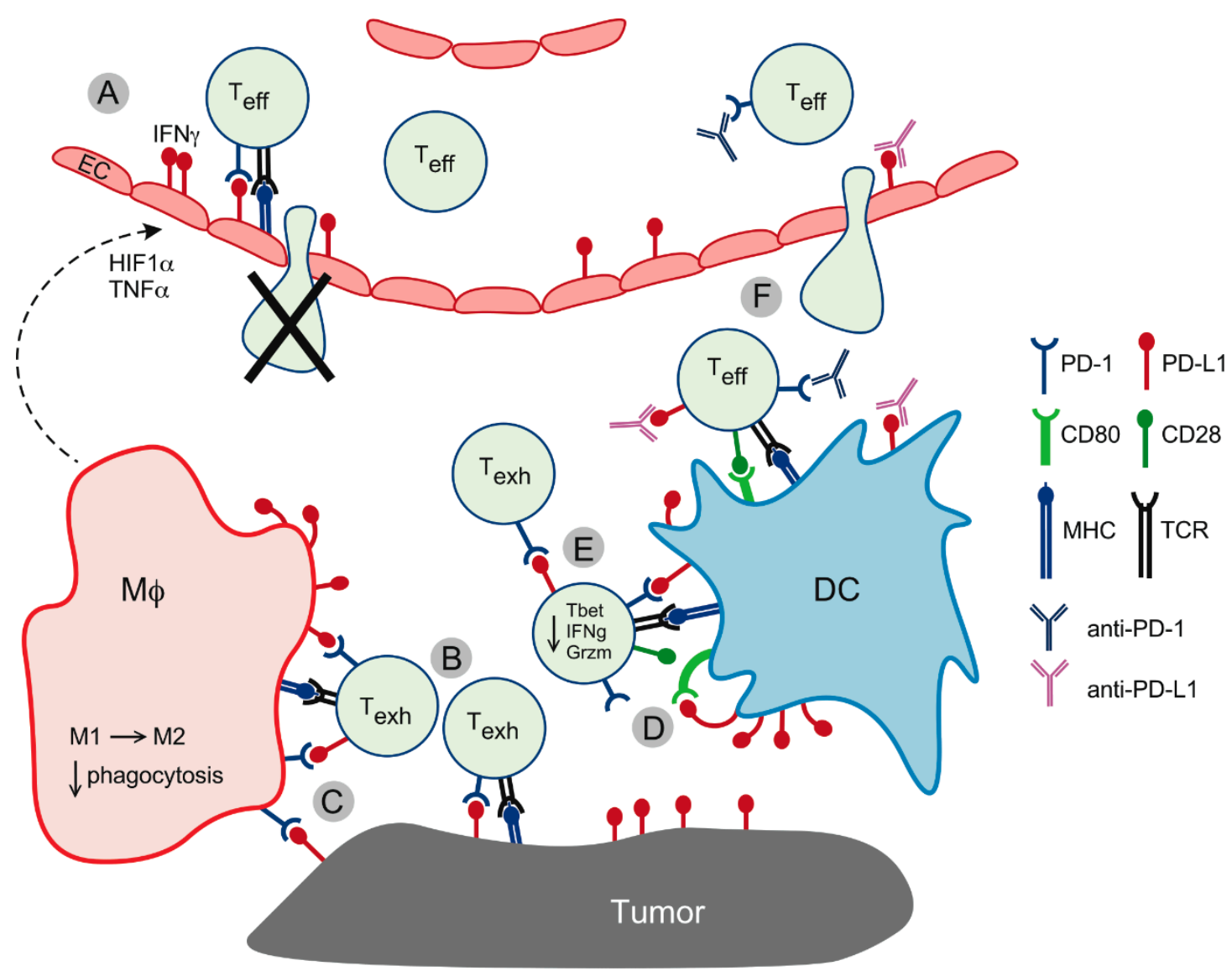

Figure 2. PD-L1-mediated cellular interactions in the tumor microenvironment. (A) PD-L1 upregulation on blood vessel endothelial cells (EC) in response to T-cell-derived IFN $\gamma$ and macrophage-derived hypoxia-inducible factor $1 \alpha(\mathrm{HIF} 1 \alpha)$ and tumor necrosis factor $\alpha(\mathrm{TNF} \alpha)$ functionally inactivates T-cells and reduces their transmigration into the tumor bed. Endothelial cells can also induce Fas-dependent T-cell death in migrating T-cells. (B) PD-L1 interacts with PD-1 on T-cells maintaining a state of exhaustion/dysfunction ( $\mathrm{T}_{\text {exh }}$ ). (C) PD-L1 expressed on T-cells interacts with PD-1-positive macrophages $(\mathrm{M} \phi)$, promoting M2 polarization and functional impairment. (D) PD-L1 on dendritic cells (DC) sequesters CD80 in cis, preventing it from interacting with CD28 on T-cells and thus abolishing T-cell activation. Excess of PD-L1 binds PD-1, contributing to T-cell exhaustion. (E) Reverse signaling via PD-L1 on T-cells impairs effector functions, such as cytokine production and killing capacity, while at the same time protecting T-cells from death, thus contributing to the expansion of functionally impaired T-cell clones. (F) Therapeutic antibodies restore T-cell effector function (Teff) by blocking PD-1 and/or PD-L1 signaling to the T-cell and releasing PD-L1-bound CD80 for interaction with CD28, thus enhancing T-cell stimulation upon antigen recognition via the T-cell receptor (TCR). In addition, therapeutic antibodies improve T-cell recruitment to the tumor by blocking PD-L1 on endothelial cells.

A recent discovery of macrophages expressing the PD-1 receptor [46] adds a layer of complexity to the biology of the PD-1/PD-L1 axis in tumor myeloid cells. PD-1-expressing TAMs were exclusively of the pro-tumorigenic M2-polarized type [46], which is in agreement with Diskin et al., who reported 
that T-cell-expressed PD-L1 could engage with TAM-expressed PD-1 to promote M2 polarization driving a cancer-permissive environment [29]. It is unclear to what extent anti-PD-1 therapeutic antibodies directly modify the biology of PD-1-expressing TAMs, but myeloid cell-targeting therapies, especially a blockade of the colony stimulating factor 1 (CSF1) receptor signaling, potently synergize with immunotherapy in preclinical models of cancer. Several ongoing clinical trials address the safety and efficacy of myeloid cell-targeting drugs combined with immune checkpoint inhibitors in advanced melanoma, renal and lung cancers (reviewed in [47]).

Endothelial cells. Abnormal angiogenesis is one of the hallmarks of cancer. Vascular endothelial cells closely guard immune cell extravasation and accumulation of T-cells in the tumor, by regulating T-cell adhesion and modulating functions of T-cells that transit through the vessel wall [48,49] (Figure 2). Endothelial cell-expressed PD-L1 suppressed CD8 T-cell cytotoxicity and cytokine production without affecting T-cell activation [50,51], and enhanced the inhibitory function of regulatory T-cells in vitro [52]. Tumor endothelial cells could also kill transmigrating CD8 T-cells via the Fas ligand-Fas interactions, while sparing regulatory T-cells that are relatively resistant to Fas-mediated apoptosis [49]. In turn, T-cells modulate endothelial cell functions via the local production of IFN $\gamma$ and TNF $\alpha[20,50,51,53]$.

Anti-angiogenic therapies trigger vascular regression and/or blood vessel normalization, allowing for the extravasation of cytotoxic T-cells, release of IFN $\gamma$ and TNF $\alpha$ and the resulting increase in PD-L1 expression on endothelial cells $[20,53,54]$. This effect could be replicated in vitro, in endothelial cells exposed to IFN $\gamma$ and TNF $\alpha$ [50,51]. IFN $\gamma$ and TNF $\alpha$ also triggered the production of immunosuppressive cytokines IL- 6 and transforming growth factor (TGF) $\beta$ that further enhanced PD-L1 expression on endothelial cells (reviewed in [55]).

Endothelial cell expression of PD-L1 plays a role in resistance to anti-angiogenic therapy, as anti-angiogenic therapy synergized with PD-1/PD-L1 blockade in several preclinical models of cancer $[20,53]$. Furthermore, anti-angiogenic therapy combined with anti-PD-1 facilitated the formation in the tumor tissue of highly specialized capillaries known as high endothelial venules (HEVs), structures normally present in lymph nodes where they serve as dedicated sites of T-cell homing, likely indicative of the development of tertiary lymphoid structures within the tumor [20]. Thus, PD-L1 expression by the tumor vasculature plays a role in limiting access and restricting the function of T-cells that enter the tumor tissue.

In summary, the non-overlapping expression patterns and the non-redundant functions of PD-1 and PD-L1 expressed on multiple cell types within the tumor microenvironment strongly suggest a potential benefit for combined PD-1/PD-L1 targeting. Combined PD-1/PD-L1 blockade is currently being investigated for safety and tolerability (clinicaltrials.gov identifier: NCT02118337).

\section{Expression of PD-L1 by Tumor Cells}

Mechanisms responsible for PD-L1 expression by tumor cells can be divided broadly into constitutive and inflammation-driven expression.

Constitutive expression of PD-L1 on tumor cells. Tumor cell-intrinsic (constitutive) expression of PD-L1 is not linked to the ongoing immune response and can be observed in the absence or presence of T-cells in tumor biopsies. Multiple mechanisms can contribute to tumor cell-intrinsic PD-L1 expression, including genetic, post-transcriptional and post-translational regulation.

Genetic events that determine PD-L1 expression. The PD-L1/CD274 gene is located on chromosome 9p24.1 in proximity to the second PD-1 ligand PD-L2 (PDCDLG2) and the gene encoding Janus kinase 2 (JAK2), the downstream kinase involved in IFN $\gamma$ receptor signaling. Copy number amplifications of 9p24.1 have been associated with increased PD-L1 expression in several cancers, and occur most commonly in mediastinal large B-cell lymphoma, classical Hodgkin's lymphoma [56] and triple-negative breast cancer [57], but have also been described in ovarian, head and neck, bladder, cervical cancers, sarcomas and colorectal cancers, albeit at lower frequencies $[8,58]$. Enhanced signaling via JAK2 in cancers with 9p24.1 amplifications, contributed to mixed inflammatory and constitutive tumor-derived PD-L1 expression [56]. In addition, tumors with CD274 genetic gains demonstrated higher mutational loads compared to 
non-amplified cases and responded particularly well to PD-1 blockade [5,59]. Deletions of PD-L1 are also commonly found in melanoma and non-small cell lung cancer, and represent one of the mechanisms leading to the lack of tumor cell PD-L1 expression $[58,60]$.

Aberrant oncogenic signaling. Oncogenic signaling is an important regulator of tumor PD-L1 expression (Figure 3). Several oncogenic transcription factors including MYC, RAS and STAT3 individually or co-operatively promote PD-L1 expression in tumor cells.

Activation and overexpression of MYC is observed in many cancers and is directly linked to tumorigenesis. MYC binds the promoter region of PD-L1 directly, upregulating PD-L1 expression in T-cell leukemia, hepatocellular carcinoma, melanoma and colorectal cancer [61]. In non-small cell lung cancer, a significant positive correlation was observed between MYC and PD-L1 expression by immunohistochemistry [62].

Oncogenic RAS signaling increases PD-L1 expression though c-Jun binding, such as in BRAF inhibitor-resistant melanoma [63], and via stabilization of PD-L1 mRNA, such as in lung and colorectal tumors [64]. Furthermore, inactivation of the tumor suppressor TP53, which is often associated with activating RAS mutations in lung adenocarcinoma and increased mutational load due to DNA damage repair defects, drives T-cell activation and immune-mediated elevation of PD-L1 expression, translating into a strong clinical benefit of PD-1 blockade in such patients [65].

Activating mutations in epidermal growth factor receptor (EGFR) drive the strong constitutive expression of tumor PD-L1 in a subset of patients with non-small cell lung cancer (reviewed in [66]). Expression of mutant EGFR was sufficient to induce PD-L1 expression in bronchial epithelial cells, while EGFR targeting reduced PD-L1 expression in EGFR-mutant tumor cells [67]. It appears that EGFR promotes PD-L1 expression by directly activating PD-L1 gene expression via the MEK/ERK/c-Jun pathway [68], as well as indirectly via IL-6/JAK/STAT3 signaling [69]. Similarly, activating mutations in the fibroblast growth factor receptor 2 (FGFR2) in colorectal cancer activate PD-L1 expression via the JAK/STAT3 pathway [70].

Oncogenic activation of STAT3 drives strong PD-L1 expression in lymphoma, by increasing STAT3 transcriptional activity and ensuring robust binding to the PD-L1 promoter [71]. Nucleophosmin-anaplastic lymphoma kinase fusion protein (NPM/ALK)-carrying T-cell lymphomas also strongly express PD-L1 via NPM/ALK-activated STAT3 [72].

In de-differentiated cancers with features of epithelial-to-mesenchymal transition (EMT), additional signaling pathways maintain PD-L1 expression, including Yes-associated protein (YAP) and $\beta$-catenin pathways (Figure 3). The Hippo pathway effector and transcriptional co-activator YAP acts in concert with the TEA domain (TEAD) family of transcription factors to regulate PD-L1 expression in de-differentiated cancers. The PD-L1 promoter has two putative TEAD binding sites [73], and YAP recruits TEAD transcription factors to the PD-L1 promoter region [73,74]. YAP augments PD-L1 expression in EGFR inhibitor-resistant lung cancer [73,74], pancreatic cancer [75], mesothelioma [76] and BRAF inhibitor-resistant melanoma [77]. The inhibition of YAP with a small molecular inhibitor or via gene knockdown decreased PD-L1 mRNA and protein expression in mesothelioma cells [76]. In human non-small cell lung cancer, nuclear YAP staining on immunohistochemistry was associated with PD-L1 expression $[73,76]$.

Activation of $\beta$-catenin signaling contributes to PD-L1 expression in de-differentiated cancers. Mechanistically, loss of the epithelial marker E-cadherin frees the E-cadherin-associated $\beta$-catenin for cytoplasmic translocation, GSK-3 $\beta$-mediated ubiquitination and proteosomal degradation [78]. Activation of wingless (WNT) signaling blocks the GSK-3 $\beta$-containing destruction complex, allowing for $\beta$-catenin translocation to the nucleus and association with the TCF/Lef- 1 family of transcription factors that bind the PD-L1 promoter to upregulate PD-L1 expression (Figure 3). $\beta$-catenin signaling also activates Zinc finger E-box binding homeobox 1 (ZEB-1) transcription factor, one of the major mediators of EMT. ZEB1 augments PD-L1 gene expression either directly by binding to the PD-L1 promoter [79] or indirectly, by repressing microRNA (miR)-200 that regulates PD-L1 mRNA decay [80]. The ZEB1-miR-200 axis is one of the major regulators of PD-L1 expression in EMT. 


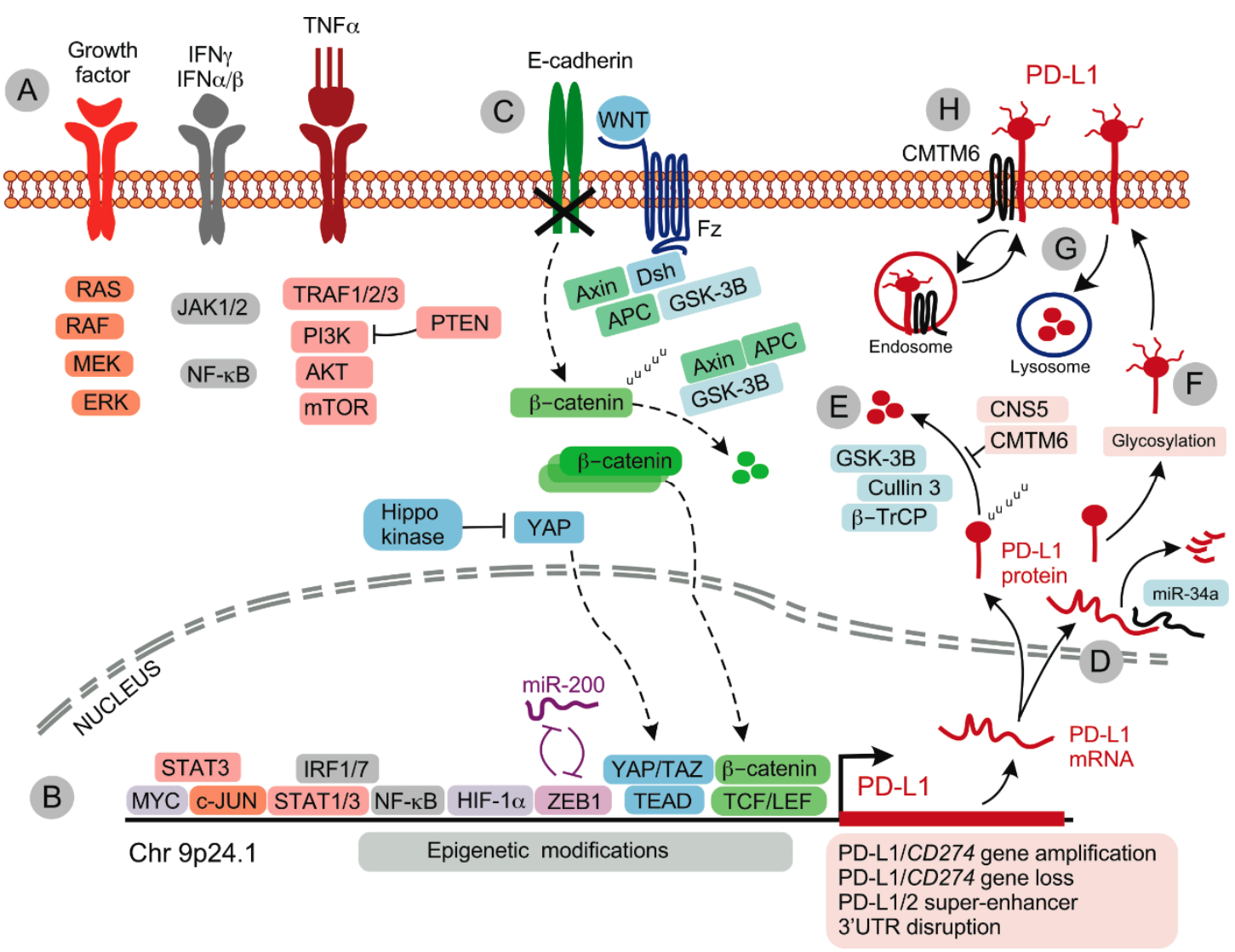

Figure 3. Regulation of PD-L1 expression in tumor cells. (A) Signaling via growth factor-, IFN- and $\mathrm{TNF} \alpha$ receptors activates multiple signaling pathways that induce PD-L1/CD274 gene expression. (B) Multiple transcription factors can induce PD-L1 expression. PD-L1 gene amplification or loss and epigenetic modifications modulate PD-L1 gene expression. (C) In de-differentiated cells undergoing epithelial-to-mesenchymal transition (EMT), loss of E-cadherin drives cytoplasmic translocation of $\beta$-catenin that is subject to ubiquitination/destruction by the Axin/APC/GSK-3B complex. Activation of Wnt/Fz/Dsh sequesters the $\beta$-catenin destruction complex and allows for the accumulation and nuclear translocation of $\beta$-catenin; $\beta$-catenin associates with TCF/LEF transcription factors to induce PD-L1 expression. ZEB1 (subject to control by miR-200) and YAP/TAZ-TEAD complexes maintain PD-L1 expression in de-differentiated phenotypes. (D) Upon transcription, PD-L1 mRNA is subject to regulation by miRs such as miR-34a. (E) PD-L1 protein is unstable, being rapidly ubiquitinated by GSK-3B and cullin $3 / \beta-\operatorname{TrCP}$, and degraded. This process is antagonized by CNS5 and CMTM6. (F) Glycosylation increases PD-L1 protein stability. (G) Cell surface-expressed PD-L1 is internalized and undergoes lysosomal degradation. (H) Alternatively, interaction with CMTM6 stabilizes PD-L1 expression by supporting endosomal recycling and preventing proteolytic degradation. Abbreviations: APC, Adenomatous polyposis coli; $\beta-\operatorname{TrCP}$, Beta-transducin repeats-containing protein; CMTM6, CKLF-like MARVEL transmembrane domain containing 6; CNS5, COP9 signalosome 5; Dsh, Dishevelled; Fz, Frizzled; GSK-3B, synthase kinase 3 beta; HIF-1 $\alpha$, Hypoxia-inducible factor- $1 \alpha$; NF-kB, Nuclear Factor kappa B; mTOR, mammalian target of rapamycin; MYC, Avian myelocytomatosis virus oncogene; PI3K, Phosphoinositide 3-kinase; PTEN, phosphatase and tensin homolog; STAT, signal transducer and activator of transcription; TCF/LEF, T-cell specific transcription factor/lymphoid enhancer binding factor; TEAD, TEA domain family member; TRAF, TNF receptor associated factor; WNT, wingless; YAP, Yes-associated protein; ZEB1, Zinc finger E-box-binding homeobox 1.

Epigenetic and post-transcriptional mechanisms also contribute to the enhanced PD-L1 expression in EMT states. For example, demethylation of the PD-L1 promoter via TGF $\beta 1$-dependent repression 
of the DNA methyltransferase DNMT1 allowed for expression of PD-L1 upon TNF $\alpha$-mediated NF-kB activation [81]. Importantly, tumor PD-L1 expression in EMT states is associated with poor responses to PD-1 blockade in a subset of patients $[80,82,83]$ due to tumor expression of additional inhibitory ligands [84-87], loss of differentiation antigens by tumor cells [88] and activation of T-cell exclusion mechanisms [89-91], collectively contributing to reduced T-cell infiltration and tumor immune escape $[86,92,93]$.

Finally, the AKT-mTOR pathway serves as a convergence point for the activation of many oncogenic pathways, and is involved in regulating PD-L1 expression at the protein level via the regulation of protein synthesis and lysosomal protein degradation [94]. Accordingly, the mTOR inhibitor rapamycin significantly reduced tumor burden in mice bearing carcinogen-induced lung tumors [94].

In addition to aberrant oncogenic signaling, other genetic mechanisms regulate PD-L1 expression. The $3^{\prime}$ untranslated region ( $3^{\prime}$-UTR) of the PD-L1 gene is commonly disrupted by structural alterations leading the production of multiple stable aberrant transcripts and the resultant elevation of PD-L1 expression [95]. An increase in PD-L1 expression due to 3'-UTR disruption is thought to interfere with post-transcriptional regulation such as miR-mediated control, resulting in a decreased mRNA decay rate [80,95-98]. A super-enhancer located between the PD-L1 and PD-L2 genes has recently been identified [99] and shown to maintain expression of PD-L1 independently of IFN $\gamma$. It is subject to epigenetic regulation and sensitized cancer cells to PD-1 blockade [99].

\section{Inducible Expression of PD-L1}

Transcriptional regulation of PD-L1 expression. A multitude of cytokines and growth factors can initiate or augment PD-L1 expression on cancer cells and in the tumor microenvironment. Of these, IFN $\gamma$ produced by TILs as a result of T-cell recognition of tumor antigens is the most potent inducer of non-constitutive PD-L1 expression in cancer cells, and in the tumor microenvironment (reviewed in [100]). Loss of IFN $\gamma$ responsiveness in tumor cells may result from inactivating mutations in JAK1/2 disrupting INF $\gamma$ signaling [101], leading to tumor immune escape and disease progression. Mechanistically, IFN $\gamma$ acts via the JAK/STAT/IRF axis [102] and NF-kB [103] to stimulate PD-L1 production. Tumor cells with disrupted IFN $\gamma$ signaling had a defective PD-L1 upregulation and were efficiently controlled by the immune system in a mouse model of melanoma [104]. Such IFN $\gamma$ signaling-deficient cancer cells required cooperation from IFN $\gamma$ signaling-sufficient and PD-L1-positive cells for immune escape, indicating the importance of PD-L1 and environmental clues for tumor immune escape. These data also suggest that disrupted IFN $\gamma$ signaling is advantageous for tumors in the context of immunotherapy [101,104].

TNF $\alpha$ can induce PD-L1 expression in the absence of IFN $\gamma$ [41]. However, in T-cell-infiltrated tumors, both cytokines are often co-produced by T-cells, and an increase in PD-L1 expression at the height of an immune response is likely to result from the concerted action of TNF $\alpha$ and IFN $\gamma$ synergizing to increase PD-L1 production. Other inflammatory mediators that upregulate PD-L1 expression in tumor and non-tumor cells include IL-6 [42], prostaglandin E2 [19] and HIF-1 $\alpha$ [38].

At the epigenetic level, regulation of PD-L1 expression is most intricately linked to DNA methylation. Hypermethylation of the PD-L1 promoter prevented PD-L1 expression [12], while a constitutive expression of PD-L1 in melanoma biopsies and cell lines was associated with global DNA hypomethylation patterns $[105,106]$. Interestingly, some of the hypomethylated cancer cells also produced high concentrations of inflammatory cytokines including IFN $\gamma$, IL-6 and IL-8 [107], suggesting that constitutive PD-L1 expression in epigenetically dysregulated cancers could be maintained, at least in part, by the IFN $\gamma$ and/or IL-6-dependent feedback loop. Other epigenetic mechanisms such as histone deacetylation and aberrant expression of the Enhancer of zeste homolog 2 (EZH2) contribute to the control of PD-L1 expression in cancer cells by limiting transcription factor access to the PD-L1 promoter region (reviewed in [12]). Accordingly, targeting epigenetic mechanisms responsible for the low/absent PD-L1 expression on cancer cells has emerged as an attractive strategy to improve efficacy of PD-1-directed immunotherapies in selected patient cohorts ([12]). 
Post-transcriptional regulation of PD-L1 expression. Multiple miRs regulate PD-L1 expression either at baseline or in response to IFN $\gamma$, by mediating mRNA degradation or by inhibiting translation. A number of miRs can bind to the $3^{\prime} \mathrm{UTR}$ of the PD-L1 gene and have been shown to directly suppress PD-L1 expression, including miR-513 [96], miR-155 [108], miR-17-5p [109], miR-33a [110], miR-34a [98] and multiple others (Table 1). In contrast, only a few miRs have been shown to increase PD-L1 expression by activation of PD-L1 transcription inducers. For example, miR-18a enhanced PD-L1 expression in cervical cancer by targeting the tumor suppressor PTEN and the Wnt/ $\beta$-catenin pathway inhibitor SOX6 to activate the PI3K/AKT, MEK/ERK and Wnt/ $\beta$-catenin pathways, respectively [111]. miR-20b, -21 and -130b upregulated PD-L1 expression in colorectal cancer also by targeting PTEN [112], while miR-135 augmented PD-L1 expression in lung cancer by suppressing the ubiquitination of proteins in the JAK/STAT signaling pathway [113].

Table 1. MiR regulation of PD-L1 expression.

\begin{tabular}{|c|c|c|c|}
\hline $\operatorname{miR}$ & $\begin{array}{l}\text { Change in PD-L1 } \\
\text { Expression }\end{array}$ & Cancer or Cell Model & Reference \\
\hline $\operatorname{miR}-15 a, 15 b$ & Decrease & Mesothelioma & [114] \\
\hline \multirow{2}{*}{ miR-16 } & \multirow{2}{*}{ Decrease } & Mesothelioma & [114] \\
\hline & & Prostate cancer & [115] \\
\hline miR-17-5p & Decrease & Melanoma (BRAF inhibitor resistant) & [109] \\
\hline $\operatorname{miR}-25$ & Decrease & Bone marrow stromal cells & [116] \\
\hline $\operatorname{miR}-33 a$ & Decrease & Lung cancer & [110] \\
\hline $\operatorname{miR}-34 a$ & Decrease & $\begin{array}{l}\text { Acute myeloid leukemia } \\
\text { Lung cancer } \\
\text { B-cell lymphomas }\end{array}$ & $\begin{array}{c}{[97,98]} \\
{[117]}\end{array}$ \\
\hline miR-93 & Decrease & Bone marrow stromal cells & [116] \\
\hline miR-106b & Decrease & Bone marrow stromal cells & [116] \\
\hline $\operatorname{miR}-138-5 p$ & Decrease & Colorectal cancer & [118] \\
\hline $\operatorname{miR}-140$ & Decrease & $\begin{array}{l}\text { Colorectal cancer } \\
\text { Lung cancer }\end{array}$ & $\begin{array}{l}{[119]} \\
{[120]}\end{array}$ \\
\hline $\operatorname{miR}-142-5 p$ & Decrease & $\begin{array}{c}\text { Pancreatic cancer } \\
\text { Lung cancer (via PTEN) }\end{array}$ & $\begin{array}{l}{[121]} \\
{[122]}\end{array}$ \\
\hline \multirow{2}{*}{$\begin{array}{l}\text { miR-148a-3p } \\
\text { miR-152 }\end{array}$} & Decrease & Colorectal cancer (MSI-high) & [123] \\
\hline & Decrease & Gastric cancer & [124] \\
\hline miR-155 & Decrease & $\begin{array}{l}\text { Endothelial cells (IFN } \gamma / \mathrm{TNF} \alpha \\
\text { response) }\end{array}$ & [108] \\
\hline miR-191-5p & Decrease & Colorectal cancer & [125] \\
\hline \multirow[t]{2}{*}{ miR-193a-3p } & \multirow[t]{2}{*}{ Decrease } & Mesothelioma & [114] \\
\hline & & Mesothelioma & [114] \\
\hline \multirow{3}{*}{ miR-195 } & \multirow{3}{*}{ Decrease } & B-cell lymphomas & [126] \\
\hline & & Pancreatic cancer & [127] \\
\hline & & Prostate cancer & [115] \\
\hline \multirow[t]{3}{*}{ miR-197 } & \multirow[t]{3}{*}{ Decrease } & Lung cancer (via CKS1B/STAT3) & [128] \\
\hline & & Lung cancer & [80] \\
\hline & & Gastric cancer & [124] \\
\hline \multirow[t]{3}{*}{ miR-200 family } & \multirow[t]{3}{*}{ Decrease } & Hepatocellular carcinoma & [129] \\
\hline & & Breast cancer & [130] \\
\hline & & Acute myeloid leukemia & [131] \\
\hline $\operatorname{miR}-217$ & Decrease & Laryngeal cancer & [132] \\
\hline $\operatorname{miR}-340$ & Decrease & Cervical cancer & [111] \\
\hline miR-375 & Decrease & Lung cancer (via JAK2/STAT1) & [133] \\
\hline $\operatorname{miR}-383$ & Decrease & Cervical cancer & [111] \\
\hline $\operatorname{miR}-424$ & Decrease & Ovarian cancer & [134] \\
\hline
\end{tabular}


Table 1. Cont.

\begin{tabular}{cccc}
\hline miR & $\begin{array}{c}\text { Change in PD-L1 } \\
\text { Expression }\end{array}$ & Cancer or Cell Model & Reference \\
\hline miR-497-5p & Decrease & Renal cell carcinoma & {$[135]$} \\
miR-513 & Decrease & Cholangiocytes & {$[96]$} \\
miR-519 & Decrease & Pancreatic cancer & {$[136]$} \\
miR-570 & Decrease & Gastric cancer & {$[137]$} \\
miR-873 & Decrease & Breast cancer & {$[138]$} \\
miR-3609 & Decrease & Cervical cancer & {$[139]$} \\
miR-18a & Increase & Colorectal cancer & {$[111]$} \\
miR-20 & Increase & Colorectal cancer & {$[112]$} \\
miR-21 & Increase & Colorectal cancer & {$[112]$} \\
miR-130b & Increase & Lung cancer & {$[113]$} \\
miR-135 & Increase & Lung cancer (via STAT3) & {$[140]$} \\
\hline miR-3127-5p & Increase &
\end{tabular}

MSI, microsatellite instability; CKS1B, CDC28 protein kinase regulatory subunit 1B; STAT3, Signal transducer and activator of transcription 3 .

\section{Regulation PD-L1 Protein Expression}

Glycosylation. PD-L1 glycosylation regulates PD-L1 protein stability and degradation. Several key regulators of glycosylation have been identified and these may offer new options for therapeutic PD-1 blockade [42,141]. Nonglycosylated PD-L1 is an unstable protein that is rapidly degraded by the ubiquitin/proteasome system after being phosphorylated by glycogen synthase kinase $3 \beta$ (GSK3 $\beta$ ) [142]. PD-L1 is heavily glycosylated [142], as are other immune inhibitory receptors and ligands including PD-1 [143]. Glycosylation improves PD-L1 stability [144] but also creates a therapeutic vulnerability, where abnormal glycosylation such as that triggered by a commonly used anti-diabetic drug metformin results in endoplasmic reticulum-associated degradation of PD-L1 and improved immune responses [145].

Glycosylation is important for the PD-L1 interaction with PD-1, and antibodies specifically targeting a glycosylated form of PD-L1 triggered immune-mediated rejection of mouse tumors expressing the human version of PD-L1 [143]. A similar result has recently been achieved with a therapeutic antibody directed against the glycosylated form of PD-1, which was superior to both nivolumab and pembrolizumab in a humanized animal model of triple-negative breast cancer [146]. These studies indicate that variations in PD-1 and PD-L1 glycosylation patterns may alter therapeutic antibody binding and therefore skew immunotherapy outcomes, particularly for PD-L1 blockade.

Aberrant glycosylation of PD-L1 in cancer cells may provide some insight into the validity of PD-L1 detection as a predictive biomarker of immunotherapy response. Morales-Betanzos et al. demonstrated, using mass spectrometry and immunohistochemistry on 22 human melanoma samples, a discrepancy in PD-L1 expression assessed by the two methods, which the authors attributed to the aberrant PD-L1 glycosylation interfering with the antibody binding on immunohistochemistry [147]. Thus, at least in some of the "PD-L1-negative" tumors, glycosylation variants of PD-L1 may be expressed that are not detectable by immunohistochemistry.

Polyubiquitination and degradation of PD-L1. PD-L1 degradation is regulated by ubiquitination/proteasome and autophagy pathways [148-151], and targeting PD-L1 degradation has emerged as an alternative strategy to improve immunotherapy efficacy. COP9 signalosome 5 (CSN5) was required for TNF $\alpha$-mediated PD-L1 stabilization in cancer cells, by inhibiting the ubiquitination and degradation of PD-L1 [148]. Blockade of CSN5 by curcumin destabilized PD-L1 and sensitized cancer to immunotherapy [148]. Similarly, activation of autophagy by verteporfin reduced PD-L1 expression in cancer cells [152].

The transmembrane protein CMTM6 and the closely related CMTM4 regulate PD-L1 cell surface expression by associating with PD-L1 in recycling endosomes and protecting PD-L1 from ubiquitination (by the E3 ubiquitin ligase STUB1) and the resulting proteosomal degradation $[149,150]$. Cyclin D-CDK4 
kinase also promotes PD-L1 ubiquitination and degradation via the cullin 3 - SPOP E3 ligase (SPOP is stabilized by Cyclin D-CDK4-mediated phosphorylation) [151]. Thus, CDK4/6 inhibitors synergized with PD-1 blockade in mouse tumor models [151]. Taken together, these observations highlight the multilayered regulation of PD-L1 expression, from transcription to protein degradation. Although most of these mechanisms have been studied in cancer cell lines, many may also operate in non-cancer cells. The exact contribution of these mechanisms to the expression of PD-L1 in myeloid and immune cells is yet to be defined.

Soluble PD-L1. Soluble PD-L1 (sPD-L1) is frequently detected in the blood of cancer patients. Three mechanisms can contribute to the release of PD-L1 into circulation: alternatively spliced transcripts [153,154], release of PD-L1 associated with extracellular vesicles such as exosomes $[155,156]$ and proteolytical cleavage from the surface of PD-L1-expressing cancer- and non-cancer cells [157].

In several studies, high levels of circulating SPD-L1 were associated with poor patient outcomes in melanoma, lung and gastric cancers and lymphoma [155,158-160] and with reduced response to PD-1 blockade in melanoma [161]. Of note, sPD-1 was also found in the blood of melanoma patients and, together with sPD-L1, predicted poor response to PD-1 blockade [161]. Some of sPD-L1 retains biological activity, including exosome-associated PD-L1 $[155,156]$ and a truncated isoform that retains the ability to form dimers and interact with PD-1 [154]. Biologically active sPD-1 and sPD-L1 may differentially interfere with therapeutic antibodies directed against PD-L1 and PD-1, respectively.

\section{Temporal Changes in PD-L1 Expression}

Early increase in PD-L1 expression is associated with response to treatment. Analysis of longitudinal biopsies in patients treated with PD-1 inhibitors revealed that an increase in PD-L1 expression compared to baseline in the first eight weeks of therapy correlated with an increase in tumor-infiltrating T-cells and was an indicator of a treatment response [162,163]. This increase in PD-L1 expression was driven by T-cell-derived IFN $\gamma$ [164] and observed on both cancer and non-cancer cells [163], with macrophage PD-L1 expression often protracted compared to cancer cells [164]. A corresponding T-cell clonal expansion was detectable in blood within one-three weeks of treatment [165], indicative of clonal replacement [166] in addition to the "invigoration" of the existing dysfunctional T-cells [165]. A similar increase in PD-L1 expression in longitudinal biopsies, combined with an immune gene expression signature, was observed in patients treated with anti-CTLA-4 antibodies [167]. Thus, an increase in PD-L1 expression in longitudinal tumor biopsies, on tumor and non-tumor cells, was a strong indicator of immunotherapy response, not limited to anti-PD-1 treatment.

PD-L1 expression in de-differentiated tumors is associated with treatment resistance. Tumors from patients who progress while on targeted therapy or immunotherapy often display features associated with hypoxia, angiogenesis, EMT program and de-differentiation [88,168,169]. These features are associated with poor patient responses to PD-1 blockade in melanoma, lung, head and neck, breast cancer and other cancer types, despite PD-L1 expression in tumor lesions [80-84,130]. TGF $\beta$ produced by tumor stromal cells helps establish the EMT program in cancer cells by driving the expression of key transcription factors ZEB, Twist, Snail and Slug [170-172] while contributing to T-cell exclusion [89]. Signaling via HIF-1 $\alpha$ [38], $\beta$-catenin [173], AXL tyrosine kinase [174,175], YAP [73,74] and ZEB1 pathways [79,80] variably contributes to augmented PD-L1 expression in de-differentiated tumors. Accordingly, pharmacological inhibition of these pathways decreased PD-L1 expression in the corresponding in vitro and in vivo models of cancer [173-175] and conferred sensitivity to PD-1/PD-L1 axis blockade [171]. TGF $\beta$ in particular represents an attractive therapeutic target for potentially reversing EMT. However, inhibition of TGF $\beta$ signaling released matrix metalloproteinase- 9 by stromal fibroblasts, resulting in cleavage of PD-L1 from the surface of PD-L1-expressing cancer cells and myeloid cells and generation of soluble PD-L1, thus potentially desensitizing to anti-PD-1 treatment [157]. Tumor heterogeneity in EMT states also contributes to variable inter- and intralesional PD-L1 expression [88], including PD-L1 expression on cancer stem cells (via increased glycosylation resulting in improved PD-L1 protein stability), further contributing to tumor immune escape [141]. 


\section{Concluding Remarks}

Immunotherapies targeting the PD-1/PD-L1 axis have demonstrated a remarkable efficacy in a range of cancers. However, many patients fail to respond, and treatment resistance remains a major obstacle with only a small proportion of patients experiencing complete responses. Expression of PD-L1 in tumor biopsies, while an imperfect biomarker predictive of response to PD-1/PD-L1-based therapies, is constantly re-evaluated to improve its predictive value. Advances in immunohistochemistry staining and scoring of PD-L1 expression in tumor lesions, independent assessment of PD-L1 expression on tumor and non-tumor cells, combining PD-L1 expression scores with other parameters such as T-cell infiltration and T-cell proximity to tumor cells, tumor mutational load and signatures of IFN $\gamma$ response help improve the predictive value of PD-L1 expression in tumor biopsies [176-178]. Yet, new evidence has uncovered some unexpected twists in the PD-1/PD-L1 biology that need to be considered when analyzing the potential outcomes of treatment or predictive value of PD-L1 expression in certain patient cohorts. A protective role of PD-L1 expressed on T-cells [27], the discovery of PD-L1 bidirectional signaling in T-cells [29] and PD-L1-mediated sequestration of T-cell activation signals on dendritic cells [17] indicate non-redundant roles for PD-1 and PD-L1 blockade and the potential for combination therapies. PD-1 expression on macrophages [46] and tumor cells [179] identifies these cell types as direct targets of PD-1 blockade and indicates the potential for unexpected treatment outcomes. For PD-1-expressing T-cell subsets, shifting the balance of response from PD- $1^{+} \mathrm{CD} 8^{+} \mathrm{T}$-cells towards $\mathrm{PD}-1^{+}$regulatory T-cell activation may reinforce immunosuppression and promote adaptive immune resistance [180]. Identification of sPD-L1 isoforms retaining biological activity [154] suggests the possibility of therapeutic anti-PD1 neutralization and immunotherapy attenuation. Characterization of glycosylated PD-L1 isoforms [147] indicates the potential for interference with immunohistochemistry-based PD-L1 detection and "false negative" results. Finally, a better understanding of the mechanisms driving antigen loss and T-cell exclusion in tumors with EMT features, as well as the strong association with progression on single-agent anti-PD-1, suggest a rationale for first-line combination immunotherapies in such patients.

There are also some exciting new treatments under investigation. Therapeutic targeting of glycosylated PD-L1 [143] and PD-1 isoforms [146], and enhancing PD-L1 degradation by disrupting endosomal recycling $[149,150]$ offer new ways of targeting the PD-1/PD-L1 pathway. Epigenetic targeting of tumor PD-L1 expression [12] can also improve tumor-specific antigen expression and the resulting T-cell recognition, thus creating new therapeutic vulnerabilities. Finally, a partial reversal of tumor EMT with TGF $\beta$-, AXL- and YAP-targeting therapies [76,171,175] may re-sensitize tumors to immunotherapies by restoring antigen expression and allowing tumor T-cell infiltration.

Author Contributions: E.S. and H.R. wrote, revised and approved the final manuscript. All authors have read and agreed to the published version of the manuscript.

Funding: This research was founded by Macquarie University, Melanoma Institute Australia and National Health and Medical Research Council of Australia (NHMRC) program grant 10930 and project grants 1130423 and 1093017. HR is supported by a NHMRC Senior Research Fellowship.

Conflicts of Interest: The authors declare no conflict of interests. The funders had no role in the design of the study; in the collection, analyses, or interpretation of data; in the writing of the manuscript, or in the decision to publish the results.

\section{References}

1. Hodi, F.S.; O’Day, S.J.; McDermott, D.F.; Weber, R.W.; Sosman, J.A.; Haanen, J.B.; Gonzalez, R.; Robert, C.; Schadendorf, D.; Hassel, J.C.; et al. Improved survival with ipilimumab in patients with metastatic melanoma. N. Engl. J. Med. 2010, 363, 711-723. [CrossRef] [PubMed]

2. Topalian, S.L.; Hodi, F.S.; Brahmer, J.R.; Gettinger, S.N.; Smith, D.C.; McDermott, D.F.; Powderly, J.D.; Carvajal, R.D.; Sosman, J.A.; Atkins, M.B.; et al. Safety, activity, and immune correlates of anti-PD-1 antibody in cancer. N. Engl. J. Med. 2012, 366, 2443-2454. [CrossRef] [PubMed] 
3. Herbst, R.S.; Soria, J.C.; Kowanetz, M.; Fine, G.D.; Hamid, O.; Gordon, M.S.; Sosman, J.A.; McDermott, D.F.; Powderly, J.D.; Gettinger, S.N.; et al. Predictive correlates of response to the anti-PD-L1 antibody MPDL3280A in cancer patients. Nature 2014, 515, 563-567. [CrossRef] [PubMed]

4. Powles, T.; Eder, J.P.; Fine, G.D.; Braiteh, F.S.; Loriot, Y.; Cruz, C.; Bellmunt, J.; Burris, H.A.; Petrylak, D.P.; Teng, S.L.; et al. MPDL3280A (anti-PD-L1) treatment leads to clinical activity in metastatic bladder cancer. Nature 2014, 515, 558-562. [CrossRef]

5. Ansell, S.M.; Lesokhin, A.M.; Borrello, I.; Halwani, A.; Scott, E.C.; Gutierrez, M.; Schuster, S.J.; Millenson, M.M.; Cattry, D.; Freeman, G.J.; et al. PD-1 blockade with nivolumab in relapsed or refractory Hodgkin's lymphoma. N. Engl. J. Med. 2015, 372, 311-319. [CrossRef]

6. Adam, J.; Le Stang, N.; Rouquette, I.; Cazes, A.; Badoual, C.; Pinot-Roussel, H.; Tixier, L.; Danel, C.; Damiola, F.; Damotte, D.; et al. Multicenter harmonization study for PD-L1 IHC testing in non-small-cell lung cancer. Ann. Oncol. 2018, 29, 953-958. [CrossRef]

7. Ribas, A.; Hu-Lieskovan, S. What does PD-L1 positive or negative mean? J. Exp. Med. 2016, 213, 2835-2840. [CrossRef]

8. Sun, C.; Mezzadra, R.; Schumacher, T.N. Regulation and Function of the PD-L1 Checkpoint. Immunity 2018, 48, 434-452. [CrossRef]

9. Taube, J.M.; Anders, R.A.; Young, G.D.; Xu, H.; Sharma, R.; McMiller, T.L.; Chen, S.; Klein, A.P.; Pardoll, D.M.; Topalian, S.L.; et al. Colocalization of inflammatory response with B7-h1 expression in human melanocytic lesions supports an adaptive resistance mechanism of immune escape. Sci. Transl. Med. 2012, 4, 127ra37. [CrossRef]

10. Gonzalez-Ericsson, P.I.; Stovgaard, E.S.; Sua, L.F.; Reisenbichler, E.; Kos, Z.; Carter, J.M.; Michiels, S.; Le Quesne, J.; Nielsen, T.O.; Laenkholm, A.V.; et al. The path to a better biomarker: Application of a risk management framework for the implementation of PD-L1 and TILs as immuno-oncology biomarkers in breast cancer clinical trials and daily practice. J. Pathol. 2020, 250, 667-684. [CrossRef]

11. Teng, M.W.; Ngiow, S.F.; Ribas, A.; Smyth, M.J. Classifying Cancers Based on T-cell Infiltration and PD-L1. Cancer Res. 2015, 75, 2139-2145. [CrossRef] [PubMed]

12. Emran, A.A.; Chatterjee, A.; Rodger, E.J.; Tiffen, J.C.; Gallagher, S.J.; Eccles, M.R.; Hersey, P. Targeting DNA Methylation and EZH2 Activity to Overcome Melanoma Resistance to Immunotherapy. Trends Immunol. 2019, 40, 328-344. [CrossRef] [PubMed]

13. McDermott, D.F.; Sosman, J.A.; Sznol, M.; Massard, C.; Gordon, M.S.; Hamid, O.; Powderly, J.D.; Infante, J.R.; Fasso, M.; Wang, Y.V.; et al. Atezolizumab, an Anti-Programmed Death-Ligand 1 Antibody, in Metastatic Renal Cell Carcinoma: Long-Term Safety, Clinical Activity, and Immune Correlates From a Phase Ia Study. J. Clin. Oncol. 2016, 34, 833-842. [CrossRef] [PubMed]

14. Ascierto, P.A.; Lewis, K.D.; Di Giacomo, A.M.; Demidov, L.; Mandala, M.; Bondarenko, I.; Herbert, C.; Mackiewicz, A.; Rutkowski, P.; Guminski, A.; et al. Prognostic impact of baseline tumour immune infiltrate on disease-free survival in patients with completely resected, BRAF(v600) mutation-positive melanoma receiving adjuvant vemurafenib. Ann. Oncol. 2020, 31, 153-159. [CrossRef] [PubMed]

15. Kluger, H.M.; Zito, C.R.; Turcu, G.; Baine, M.K.; Zhang, H.; Adeniran, A.; Sznol, M.; Rimm, D.L.; Kluger, Y.; Chen, L.; et al. PD-L1 Studies Across Tumor Types, Its Differential Expression and Predictive Value in Patients Treated with Immune Checkpoint Inhibitors. Clin. Cancer Res. 2017, 23, 4270-4279. [CrossRef] [PubMed]

16. Juneja, V.R.; McGuire, K.A.; Manguso, R.T.; LaFleur, M.W.; Collins, N.; Haining, W.N.; Freeman, G.J.; Sharpe, A.H. PD-L1 on tumor cells is sufficient for immune evasion in immunogenic tumors and inhibits CD8 T cell cytotoxicity. J. Exp. Med. 2017, 214, 895-904. [CrossRef]

17. Mayoux, M.; Roller, A.; Pulko, V.; Sammicheli, S.; Chen, S.; Sum, E.; Jost, C.; Fransen, M.F.; Buser, R.B.; Kowanetz, M.; et al. Dendritic cells dictate responses to PD-L1 blockade cancer immunotherapy. Sci. Transl. Med. 2020, 12, eaav7431. [CrossRef]

18. Lin, H.; Wei, S.; Hurt, E.M.; Green, M.D.; Zhao, L.; Vatan, L.; Szeliga, W.; Herbst, R.; Harms, P.W.; Fecher, L.A.; et al. Host expression of PD-L1 determines efficacy of PD-L1 pathway blockade-mediated tumor regression. J. Clin. Investig. 2018, 128, 805-815. [CrossRef]

19. Prima, V.; Kaliberova, L.N.; Kaliberov, S.; Curiel, D.T.; Kusmartsev, S. COX2/mPGES1/PGE2 pathway regulates PD-L1 expression in tumor-associated macrophages and myeloid-derived suppressor cells. Proc. Natl. Acad. Sci. USA 2017, 114, 1117-1122. [CrossRef] 
20. Allen, E.; Jabouille, A.; Rivera, L.B.; Lodewijckx, I.; Missiaen, R.; Steri, V.; Feyen, K.; Tawney, J.; Hanahan, D.; Michael, I.P.; et al. Combined antiangiogenic and anti-PD-L1 therapy stimulates tumor immunity through HEV formation. Sci. Transl. Med. 2017, 9, eaak9679. [CrossRef]

21. Teramoto, K.; Igarashi, T.; Kataoka, Y.; Ishida, M.; Hanaoka, J.; Sumimoto, H.; Daigo, Y. Clinical significance of PD-L1-positive cancer-associated fibroblasts in pN0M0 non-small cell lung cancer. Lung Cancer 2019, 137, 56-63. [CrossRef] [PubMed]

22. Ayers, M.; Lunceford, J.; Nebozhyn, M.; Murphy, E.; Loboda, A.; Kaufman, D.R.; Albright, A.; Cheng, J.D.; Kang, S.P.; Shankaran, V.; et al. IFN-gamma-related mRNA profile predicts clinical response to PD-1 blockade. J. Clin. Investig. 2017, 127, 2930-2940. [CrossRef] [PubMed]

23. Cristescu, R.; Mogg, R.; Ayers, M.; Albright, A.; Murphy, E.; Yearley, J.; Sher, X.; Liu, X.Q.; Lu, H.; Nebozhyn, M.; et al. Pan-tumor genomic biomarkers for PD-1 checkpoint blockade-based immunotherapy. Science 2018, 362, eaar3593. [CrossRef] [PubMed]

24. Bald, T.; Landsberg, J.; Lopez-Ramos, D.; Renn, M.; Glodde, N.; Jansen, P.; Gaffal, E.; Steitz, J.; Tolba, R.; Kalinke, U.; et al. Immune cell-poor melanomas benefit from PD-1 blockade after targeted type I IFN activation. Cancer Discov. 2014, 4, 674-687. [CrossRef]

25. Sugiura, D.; Maruhashi, T.; Okazaki, I.M.; Shimizu, K.; Maeda, T.K.; Takemoto, T.; Okazaki, T. Restriction of PD-1 function by cis-PD-L1/CD80 interactions is required for optimal T cell responses. Science 2019, 364, 558-566. [CrossRef]

26. Miller, B.C.; Sen, D.R.; Al Abosy, R.; Bi, K.; Virkud, Y.V.; LaFleur, M.W.; Yates, K.B.; Lako, A.; Felt, K.; Naik, G.S.; et al. Subsets of exhausted CD8(+) T cells differentially mediate tumor control and respond to checkpoint blockade. Nat. Immunol. 2019, 20, 326-336. [CrossRef]

27. Pulko, V.; Harris, K.J.; Liu, X.; Gibbons, R.M.; Harrington, S.M.; Krco, C.J.; Kwon, E.D.; Dong, H. B7-h1 expressed by activated CD8 T cells is essential for their survival. J. Immunol. 2011, 187, 5606-5614. [CrossRef]

28. Saha, A.; O'Connor, R.S.; Thangavelu, G.; Lovitch, S.B.; Dandamudi, D.B.; Wilson, C.B.; Vincent, B.G.; Tkachev, V.; Pawlicki, J.M.; Furlan, S.N.; et al. Programmed death ligand-1 expression on donor T cells drives graft-versus-host disease lethality. J. Clin. Investig. 2016, 126, 2642-2660. [CrossRef]

29. Diskin, B.; Adam, S.; Cassini, M.F.; Sanchez, G.; Liria, M.; Aykut, B.; Buttar, C.; Li, E.; Sundberg, B.; Salas, R.D.; et al. PD-L1 engagement on T cells promotes self-tolerance and suppression of neighboring macrophages and effector T cells in cancer. Nat. Immunol. 2020, 21, 442-454. [CrossRef]

30. Liu, X.; Wu, X.; Cao, S.; Harrington, S.M.; Yin, P.; Mansfield, A.S.; Dong, H. B7-H1 antibodies lose antitumor activity due to activation of p38 MAPK that leads to apoptosis of tumor-reactive CD8(+) T cells. Sci. Rep. 2016, 6, 36722. [CrossRef]

31. Taylor, P.A.; Lees, C.J.; Fournier, S.; Allison, J.P.; Sharpe, A.H.; Blazar, B.R. B7 expression on T cells down-regulates immune responses through CTLA-4 ligation via T-T interactions [corrections]. J. Immunol. 2004, 172, 34-39. [CrossRef] [PubMed]

32. Gabrilovich, D.I.; Ostrand-Rosenberg, S.; Bronte, V. Coordinated regulation of myeloid cells by tumours. Nat. Rev. Immunol. 2012, 12, 253-268. [CrossRef] [PubMed]

33. Antonios, J.P.; Soto, H.; Everson, R.G.; Moughon, D.; Orpilla, J.R.; Shin, N.P.; Sedighim, S.; Treger, J.; Odesa, S.; Tucker, A.; et al. Immunosuppressive tumor-infiltrating myeloid cells mediate adaptive immune resistance via a PD-1/PD-L1 mechanism in glioblastoma. Neuro Oncol. 2017, 19, 796-807. [CrossRef] [PubMed]

34. Scholz, A.; Lang, V.; Henschler, R.; Czabanka, M.; Vajkoczy, P.; Chavakis, E.; Drynski, J.; Harter, P.N.; Mittelbronn, M.; Dumont, D.J.; et al. Angiopoietin-2 promotes myeloid cell infiltration in a beta(2)-integrin-dependent manner. Blood 2011, 118, 5050-5059. [CrossRef] [PubMed]

35. Coffelt, S.B.; Chen, Y.Y.; Muthana, M.; Welford, A.F.; Tal, A.O.; Scholz, A.; Plate, K.H.; Reiss, Y.; Murdoch, C.; De Palma, M.; et al. Angiopoietin 2 stimulates TIE2-expressing monocytes to suppress $\mathrm{T}$ cell activation and to promote regulatory T cell expansion. J. Immunol. 2011, 186, 4183-4190. [CrossRef] [PubMed]

36. Mazzieri, R.; Pucci, F.; Moi, D.; Zonari, E.; Ranghetti, A.; Berti, A.; Politi, L.S.; Gentner, B.; Brown, J.L.; Naldini, L.; et al. Targeting the ANG2/TIE2 axis inhibits tumor growth and metastasis by impairing angiogenesis and disabling rebounds of proangiogenic myeloid cells. Cancer Cell 2011, 19, 512-526. [CrossRef]

37. Lequeux, A.; Noman, M.Z.; Xiao, M.; Sauvage, D.; Van Moer, K.; Viry, E.; Bocci, I.; Hasmim, M.; Bosseler, M.; Berchem, G.; et al. Impact of hypoxic tumor microenvironment and tumor cell plasticity on the expression of immune checkpoints. Cancer Lett. 2019, 458, 13-20. [CrossRef] 
38. Noman, M.Z.; Desantis, G.; Janji, B.; Hasmim, M.; Karray, S.; Dessen, P.; Bronte, V.; Chouaib, S. PD-L1 is a novel direct target of HIF-1alpha, and its blockade under hypoxia enhanced MDSC-mediated T cell activation. J. Exp. Med. 2014, 211, 781-790. [CrossRef]

39. Chen, D.P.; Ning, W.R.; Jiang, Z.Z.; Peng, Z.P.; Zhu, L.Y.; Zhuang, S.M.; Kuang, D.M.; Zheng, L.; Wu, Y. Glycolytic activation of peritumoral monocytes fosters immune privilege via the PFKFB3-PD-L1 axis in human hepatocellular carcinoma. J. Hepatol. 2019, 71, 333-343. [CrossRef]

40. Jeong, H.; Kim, S.; Hong, B.J.; Lee, C.J.; Kim, Y.E.; Bok, S.; Oh, J.M.; Gwak, S.H.; Yoo, M.Y.; Lee, M.S.; et al. Tumor-Associated Macrophages Enhance Tumor Hypoxia and Aerobic Glycolysis. Cancer Res. 2019, 79, 795-806. [CrossRef]

41. Hartley, G.; Regan, D.; Guth, A.; Dow, S. Regulation of PD-L1 expression on murine tumor-associated monocytes and macrophages by locally produced TNF-alpha. Cancer Immunol. Immunother. 2017, 66, 523-535. [CrossRef] [PubMed]

42. Chan, L.C.; Li, C.W.; Xia, W.; Hsu, J.M.; Lee, H.H.; Cha, J.H.; Wang, H.L.; Yang, W.H.; Yen, E.Y.; Chang, W.C.; et al. IL-6/JAK1 pathway drives PD-L1 Y112 phosphorylation to promote cancer immune evasion. J. Clin. Investig. 2019, 129, 3324-3338. [CrossRef] [PubMed]

43. Schreiner, B.; Mitsdoerffer, M.; Kieseier, B.C.; Chen, L.; Hartung, H.P.; Weller, M.; Wiendl, H. Interferon-beta enhances monocyte and dendritic cell expression of B7-H1 (PD-L1), a strong inhibitor of autologous T-cell activation: Relevance for the immune modulatory effect in multiple sclerosis. J. Neuroimmunol. 2004, 155, 172-182. [CrossRef] [PubMed]

44. Brown, J.A.; Dorfman, D.M.; Ma, F.R.; Sullivan, E.L.; Munoz, O.; Wood, C.R.; Greenfield, E.A.; Freeman, G.J. Blockade of programmed death-1 ligands on dendritic cells enhances $T$ cell activation and cytokine production. J. Immunol. 2003, 170, 1257-1266. [CrossRef]

45. Kryczek, I.; Wei, S.; Gong, W.; Shu, X.; Szeliga, W.; Vatan, L.; Chen, L.; Wang, G.; Zou, W. Cutting edge: IFN-gamma enables APC to promote memory Th17 and abate Th1 cell development. J. Immunol. 2008, 181, 5842-5846. [CrossRef]

46. Gordon, S.R.; Maute, R.L.; Dulken, B.W.; Hutter, G.; George, B.M.; McCracken, M.N.; Gupta, R.; Tsai, J.M.; Sinha, R.; Corey, D.; et al. PD-1 expression by tumour-associated macrophages inhibits phagocytosis and tumour immunity. Nature 2017, 545, 495-499. [CrossRef]

47. Weber, R.; Fleming, V.; Hu, X.; Nagibin, V.; Groth, C.; Altevogt, P.; Utikal, J.; Umansky, V. Myeloid-Derived Suppressor Cells Hinder the Anti-Cancer Activity of Immune Checkpoint Inhibitors. Front. Immunol. 2018, 9, 1310. [CrossRef]

48. Dirkx, A.E.; Oude Egbrink, M.G.; Kuijpers, M.J.; van der Niet, S.T.; Heijnen, V.V.; Bouma-ter Steege, J.C.; Wagstaff, J.; Griffioen, A.W. Tumor angiogenesis modulates leukocyte-vessel wall interactions in vivo by reducing endothelial adhesion molecule expression. Cancer Res. 2003, 63, 2322-2329.

49. Motz, G.T.; Santoro, S.P.; Wang, L.P.; Garrabrant, T.; Lastra, R.R.; Hagemann, I.S. Tumor endothelium FasL establishes a selective immune barrier promoting tolerance in tumors. Nat. Med. 2014, 20, 607-615. [CrossRef]

50. Mazanet, M.M.; Hughes, C.C. B7-H1 is expressed by human endothelial cells and suppresses T cell cytokine synthesis. J. Immunol. 2002, 169, 3581-3588. [CrossRef]

51. Rodig, N.; Ryan, T.; Allen, J.A.; Pang, H.; Grabie, N.; Chernova, T.; Greenfield, E.A.; Liang, S.C.; Sharpe, A.H.; Lichtman, A.H.; et al. Endothelial expression of PD-L1 and PD-L2 down-regulates CD8+ T cell activation and cytolysis. Eur. J. Immunol. 2003, 33, 3117-3126. [CrossRef] [PubMed]

52. Chen, W.J.; Hu, X.F.; Yan, M.; Zhang, W.Y.; Mao, X.B.; Shu, Y.W. Human umbilical vein endothelial cells promote the inhibitory activation of $\mathrm{CD} 4(+) \mathrm{CD} 25(+)$ Foxp3(+) regulatory T cells via PD-L1. Atherosclerosis 2016, 244, 108-112. [CrossRef] [PubMed]

53. Schmittnaegel, M.; Rigamonti, N.; Kadioglu, E.; Cassara, A.; Wyser Rmili, C.; Kiialainen, A.; Kienast, Y.; Mueller, H.J.; Ooi, C.H.; Laoui, D.; et al. Dual angiopoietin-2 and VEGFA inhibition elicits antitumor immunity that is enhanced by PD-1 checkpoint blockade. Sci. Transl. Med. 2017, 9, eaak9670. [CrossRef] [PubMed]

54. Liu, X.D.; Hoang, A.; Zhou, L.; Kalra, S.; Yetil, A.; Sun, M.; Ding, Z.; Zhang, X.; Bai, S.; German, P.; et al. Resistance to Antiangiogenic Therapy Is Associated with an Immunosuppressive Tumor Microenvironment in Metastatic Renal Cell Carcinoma. Cancer Immunol. Res. 2015, 3, 1017-1029. [CrossRef] 
55. Lanitis, E.; Irving, M.; Coukos, G. Targeting the tumor vasculature to enhance $\mathrm{T}$ cell activity. Curr. Opin. Immunol. 2015, 33, 55-63. [CrossRef]

56. Green, M.R.; Monti, S.; Rodig, S.J.; Juszczynski, P.; Currie, T.; O’Donnell, E.; Chapuy, B.; Takeyama, K.; Neuberg, D.; Golub, T.R.; et al. Integrative analysis reveals selective 9p24.1 amplification, increased PD-1 ligand expression, and further induction via JAK2 in nodular sclerosing Hodgkin lymphoma and primary mediastinal large B-cell lymphoma. Blood 2010, 116, 3268-3277. [CrossRef]

57. Barrett, M.T.; Anderson, K.S.; Lenkiewicz, E.; Andreozzi, M.; Cunliffe, H.E.; Klassen, C.L.; Dueck, A.C.; McCullough, A.E.; Reddy, S.K.; Ramanathan, R.K.; et al. Genomic amplification of 9p24.1 targeting JAK2, PD-L1, and PD-L2 is enriched in high-risk triple negative breast cancer. Oncotarget 2015, 6, 26483-26493. [CrossRef]

58. Budczies, J.; Bockmayr, M.; Denkert, C.; Klauschen, F.; Groschel, S.; Darb-Esfahani, S.; Pfarr, N.; Leichsenring, J.; Onozato, M.L.; Lennerz, J.K.; et al. Pan-cancer analysis of copy number changes in programmed death-ligand 1 (PD-L1, CD274)-associations with gene expression, mutational load, and survival. Genes Chromosomes Cancer 2016, 55, 626-639. [CrossRef]

59. George, J.; Saito, M.; Tsuta, K.; Iwakawa, R.; Shiraishi, K.; Scheel, A.H.; Uchida, S.; Watanabe, S.I.; Nishikawa, R.; Noguchi, M.; et al. Genomic Amplification of CD274 (PD-L1) in Small-Cell Lung Cancer. Clin. Cancer Res. 2017, 23, 1220-1226. [CrossRef]

60. Lamberti, G.; Spurr, L.F.; Li, Y.; Ricciuti, B.; Recondo, G.; Umeton, R.; Nishino, M.; Sholl, L.M.; Meyerson, M.L.; Cherniack, A.D.; et al. Clinicopathological and genomic correlates of programmed cell death ligand 1 (PD-L1) expression in nonsquamous non-small-cell lung cancer. Ann. Oncol. 2020. [CrossRef]

61. Casey, S.C.; Tong, L.; Li, Y.; Do, R.; Walz, S.; Fitzgerald, K.N.; Gouw, A.M.; Baylot, V.; Gutgemann, I.; Eilers, M.; et al. MYC regulates the antitumor immune response through CD47 and PD-L1. Science 2016, 352, 227-231. [CrossRef] [PubMed]

62. Kim, E.Y.; Kim, A.; Kim, S.K.; Chang, Y.S. MYC expression correlates with PD-L1 expression in non-small cell lung cancer. Lung Cancer 2017, 110, 63-67. [CrossRef] [PubMed]

63. Jiang, X.; Zhou, J.; Giobbie-Hurder, A.; Wargo, J.; Hodi, F.S. The activation of MAPK in melanoma cells resistant to BRAF inhibition promotes PD-L1 expression that is reversible by MEK and PI3K inhibition. Clin. Cancer Res. 2013, 19, 598-609. [CrossRef] [PubMed]

64. Coelho, M.A.; de Carne Trecesson, S.; Rana, S.; Zecchin, D.; Moore, C.; Molina-Arcas, M.; East, P.; Spencer-Dene, B.; Nye, E.; Barnouin, K.; et al. Oncogenic RAS Signaling Promotes Tumor Immunoresistance by Stabilizing PD-L1 mRNA. Immunity 2017, 47, 1083-1099.e6. [CrossRef]

65. Dong, Z.Y.; Zhong, W.Z.; Zhang, X.C.; Su, J.; Xie, Z.; Liu, S.Y.; Tu, H.Y.; Chen, H.J.; Sun, Y.L.; Zhou, Q.; et al. Potential Predictive Value of TP53 and KRAS Mutation Status for Response to PD-1 Blockade Immunotherapy in Lung Adenocarcinoma. Clin. Cancer Res. 2017, 23, 3012-3024. [CrossRef]

66. Hsu, P.C.; Jablons, D.M.; Yang, C.T.; You, L. Epidermal Growth Factor Receptor (EGFR) Pathway, Yes-Associated Protein (YAP) and the Regulation of Programmed Death-Ligand 1 (PD-L1) in Non-Small Cell Lung Cancer (NSCLC). Int. J. Mol. Sci. 2019, 20, 3821. [CrossRef]

67. Akbay, E.A.; Koyama, S.; Carretero, J.; Altabef, A.; Tchaicha, J.H.; Christensen, C.L.; Mikse, O.R.; Cherniack, A.D.; Beauchamp, E.M.; Pugh, T.J.; et al. Activation of the PD-1 pathway contributes to immune escape in EGFR-driven lung tumors. Cancer Discov. 2013, 3, 1355-1363. [CrossRef]

68. Chen, N.; Fang, W.; Zhan, J.; Hong, S.; Tang, Y.; Kang, S.; Zhang, Y.; He, X.; Zhou, T.; Qin, T.; et al. Upregulation of PD-L1 by EGFR Activation Mediates the Immune Escape in EGFR-Driven NSCLC: Implication for Optional Immune Targeted Therapy for NSCLC Patients with EGFR Mutation. J. Thorac. Oncol. 2015, 10, 910-923. [CrossRef]

69. Zhang, N.; Zeng, Y.; Du, W.; Zhu, J.; Shen, D.; Liu, Z.; Huang, J.A. The EGFR pathway is involved in the regulation of PD-L1 expression via the IL-6/JAK/STAT3 signaling pathway in EGFR-mutated non-small cell lung cancer. Int. J. Oncol. 2016, 49, 1360-1368. [CrossRef]

70. Li, P.; Huang, T.; Zou, Q.; Liu, D.; Wang, Y.; Tan, X.; Wei, Y.; Qiu, H. FGFR2 Promotes Expression of PD-L1 in Colorectal Cancer via the JAK/STAT3 Signaling Pathway. J. Immunol. 2019, 202, 3065-3075. [CrossRef]

71. Song, T.L.; Nairismagi, M.L.; Laurensia, Y.; Lim, J.Q.; Tan, J.; Li, Z.M.; Pang, W.L.; Kizhakeyil, A.; Wijaya, G.C.; Huang, D.C.; et al. Oncogenic activation of the STAT3 pathway drives PD-L1 expression in natural killer/T-cell lymphoma. Blood 2018, 132, 1146-1158. [CrossRef] [PubMed] 
72. Marzec, M.; Zhang, Q.; Goradia, A.; Raghunath, P.N.; Liu, X.; Paessler, M.; Wang, H.Y.; Wysocka, M.; Cheng, M.; Ruggeri, B.A.; et al. Oncogenic kinase NPM/ALK induces through STAT3 expression of immunosuppressive protein CD274 (PD-L1, B7-H1). Proc. Natl. Acad. Sci. USA 2008, 105, 20852-20857. [CrossRef] [PubMed]

73. Miao, J.; Hsu, P.C.; Yang, Y.L.; Xu, Z.; Dai, Y.; Wang, Y.; Chan, G.; Huang, Z.; Hu, B.; Li, H.; et al. YAP regulates PD-L1 expression in human NSCLC cells. Oncotarget 2017, 8, 114576-114587. [CrossRef] [PubMed]

74. Lee, B.S.; Park, D.I.; Lee, D.H.; Lee, J.E.; Yeo, M.K.; Park, Y.H.; Lim, D.S.; Choi, W.; Lee, D.H.; Yoo, G.; et al. Hippo effector YAP directly regulates the expression of PD-L1 transcripts in EGFR-TKI-resistant lung adenocarcinoma. Biochem. Biophys. Res. Commun. 2017, 491, 493-499. [CrossRef]

75. Murakami, S.; Shahbazian, D.; Surana, R.; Zhang, W.; Chen, H.; Graham, G.T.; White, S.M.; Weiner, L.M.; Yi, C. Yes-associated protein mediates immune reprogramming in pancreatic ductal adenocarcinoma. Oncogene 2017, 36, 1232-1244. [CrossRef]

76. Hsu, P.C.; Miao, J.; Wang, Y.C.; Zhang, W.Q.; Yang, Y.L.; Wang, C.W.; Yang, C.T.; Huang, Z.; You, J.; $\mathrm{Xu}, \mathrm{Z}$;; et al. Inhibition of yes-associated protein down-regulates PD-L1 (CD274) expression in human malignant pleural mesothelioma. J. Cell Mol. Med. 2018, 22, 3139-3148. [CrossRef]

77. Kim, M.H.; Kim, C.G.; Kim, S.K.; Shin, S.J.; Choe, E.A.; Park, S.H.; Shin, E.C.; Kim, J. YAP-Induced PD-L1 Expression Drives Immune Evasion in BRAFi-Resistant Melanoma. Cancer Immunol. Res. 2018, 6, 255-266. [CrossRef]

78. Christofori, G. New signals from the invasive front. Nature 2006, 441, 444-450. [CrossRef]

79. Tsutsumi, S.; Saeki, H.; Nakashima, Y.; Ito, S.; Oki, E.; Morita, M.; Oda, Y.; Okano, S.; Maehara, Y. Programmed death-ligand 1 expression at tumor invasive front is associated with epithelial-mesenchymal transition and poor prognosis in esophageal squamous cell carcinoma. Cancer Sci. 2017, 108, 1119-1127. [CrossRef]

80. Chen, L.; Gibbons, D.L.; Goswami, S.; Cortez, M.A.; Ahn, Y.H.; Byers, L.A.; Zhang, X.; Yi, X.; Dwyer, D.; Lin, W.; et al. Metastasis is regulated via microRNA-200/ZEB1 axis control of tumour cell PD-L1 expression and intratumoral immunosuppression. Nat. Commun. 2014, 5, 5241. [CrossRef]

81. Asgarova, A.; Asgarov, K.; Godet, Y.; Peixoto, P.; Nadaradjane, A.; Boyer-Guittaut, M.; Galaine, J.; Guenat, D.; Mougey, V.; Perrard, J.; et al. PD-L1 expression is regulated by both DNA methylation and NF-kB during EMT signaling in non-small cell lung carcinoma. Oncoimmunology 2018, 7, e1423170. [CrossRef] [PubMed]

82. Wang, Y.; Hu, J.; Wang, Y.; Ye, W.; Zhang, X.; Ju, H.; Xu, D.; Liu, L.; Ye, D.; Zhang, L.; et al. EGFR activation induced Snail-dependent EMT and myc-dependent PD-L1 in human salivary adenoid cystic carcinoma cells. Cell Cycle 2018, 17, 1457-1470. [CrossRef] [PubMed]

83. Ock, C.Y.; Kim, S.; Keam, B.; Kim, M.; Kim, T.M.; Kim, J.H.; Jeon, Y.K.; Lee, J.S.; Kwon, S.K.; Hah, J.H.; et al. PD-L1 expression is associated with epithelial-mesenchymal transition in head and neck squamous cell carcinoma. Oncotarget 2016, 7, 15901-15914. [CrossRef] [PubMed]

84. Mak, M.P.; Tong, P.; Diao, L.; Cardnell, R.J.; Gibbons, D.L.; William, W.N.; Skoulidis, F.; Parra, E.R.; Rodriguez-Canales, J.; Wistuba, I.I.; et al. A Patient-Derived, Pan-Cancer EMT Signature Identifies Global Molecular Alterations and Immune Target Enrichment Following Epithelial-to-Mesenchymal Transition. Clin. Cancer Res. 2016, 22, 609-620. [CrossRef]

85. Lou, Y.; Diao, L.; Cuentas, E.R.; Denning, W.L.; Chen, L.; Fan, Y.H.; Byers, L.A.; Wang, J.; Papadimitrakopoulou, V.A.; Behrens, C.; et al. Epithelial-Mesenchymal Transition Is Associated with a Distinct Tumor Microenvironment Including Elevation of Inflammatory Signals and Multiple Immune Checkpoints in Lung Adenocarcinoma. Clin. Cancer Res. 2016, 22, 3630-3642. [CrossRef] [PubMed]

86. Sweis, R.F.; Spranger, S.; Bao, R.; Paner, G.P.; Stadler, W.M.; Steinberg, G.; Gajewski, T.F. Molecular Drivers of the Non-T-cell-Inflamed Tumor Microenvironment in Urothelial Bladder Cancer. Cancer Immunol. Res. 2016, 4, 563-568. [CrossRef] [PubMed]

87. Sridharan, V.; Gjini, E.; Liao, X.; Chau, N.G.; Haddad, R.I.; Severgnini, M.; Hammerman, P.; El-Naggar, A.; Freeman, G.J.; Hodi, F.S.; et al. Immune Profiling of Adenoid Cystic Carcinoma: PD-L2 Expression and Associations with Tumor-Infiltrating Lymphocytes. Cancer Immunol. Res. 2016, 4, 679-687. [CrossRef]

88. Lee, J.H.; Shklovskaya, E.; Lim, S.Y.; Carlino, M.S.; Menzies, A.M.; Stewart, A.; Pedersen, B.; Irvine, M.; Alavi, S.; Yang, J.Y.H.; et al. Transcriptional downregulation of MHC class I and melanoma de- differentiation in resistance to PD-1 inhibition. Nat. Commun. 2020, 11, 1897. [CrossRef] 
89. Spranger, S.; Bao, R.; Gajewski, T.F. Melanoma-intrinsic beta-catenin signalling prevents anti-tumour immunity. Nature 2015, 523, 231-235. [CrossRef]

90. Spranger, S.; Dai, D.; Horton, B.; Gajewski, T.F. Tumor-Residing Batf3 Dendritic Cells Are Required for Effector T Cell Trafficking and Adoptive T Cell Therapy. Cancer Cell 2017, 31, 711-723.e4. [CrossRef]

91. Wang, L.; Saci, A.; Szabo, P.M.; Chasalow, S.D.; Castillo-Martin, M.; Domingo-Domenech, J. EMT-and stroma-related gene expression and resistance to PD-1 blockade in urothelial cancer. Nat. Commun. 2018, 9 , 3503. [CrossRef] [PubMed]

92. Grasso, C.S.; Giannakis, M.; Wells, D.K.; Hamada, T.; Mu, X.J.; Quist, M.; Nowak, J.A.; Nishihara, R.; Qian, Z.R.; Inamura, K.; et al. Genetic Mechanisms of Immune Evasion in Colorectal Cancer. Cancer Discov. 2018, 8, 730-749. [CrossRef] [PubMed]

93. Jiménez-Sánchez, A.; Memon, D.; Pourpe, S.; Veeraraghavan, H.; Li, Y.; Vargas, H.A.; Gill, M.B.; Park, K.J.; Zivanovic, O.; Konner, J.; et al. Heterogeneous Tumor-Immune Microenvironments among Differentially Growing Metastases in an Ovarian Cancer Patient. Cell 2017, 170, 927-938.e20. [CrossRef] [PubMed]

94. Lastwika, K.J.; Wilson, W., 3rd; Li, Q.K.; Norris, J.; Xu, H.; Ghazarian, S.R.; Kitagawa, H.; Kawabata, S.; Taube, J.M.; Yao, S.; et al. Control of PD-L1 Expression by Oncogenic Activation of the AKT-mTOR Pathway in Non-Small Cell Lung Cancer. Cancer Res. 2016, 76, 227-238. [CrossRef]

95. Kataoka, K.; Shiraishi, Y.; Takeda, Y.; Sakata, S.; Matsumoto, M.; Nagano, S.; Maeda, T.; Nagata, Y.; Kitanaka, A.; Mizuno, S.; et al. Aberrant PD-L1 expression through 3'-UTR disruption in multiple cancers. Nature 2016, 534, 402-406. [CrossRef] [PubMed]

96. Gong, A.Y.; Zhou, R.; Hu, G.; Li, X.; Splinter, P.L.; O’Hara, S.P.; LaRusso, N.F.; Soukup, G.A.; Dong, H.; Chen, X.M. MicroRNA-513 regulates B7-H1 translation and is involved in IFN-gamma-induced B7-H1 expression in cholangiocytes. J. Immunol. 2009, 182, 1325-1333. [CrossRef]

97. Wang, X.; Li, J.; Dong, K.; Lin, F.; Long, M.; Ouyang, Y.; Wei, J.; Chen, X.; Weng, Y.; He, T.; et al. Tumor suppressor miR-34a targets PD-L1 and functions as a potential immunotherapeutic target in acute myeloid leukemia. Cell. Signal. 2015, 27, 443-452. [CrossRef]

98. Cortez, M.A.; Ivan, C.; Valdecanas, D.; Wang, X.; Peltier, H.J.; Ye, Y.; Araujo, L.; Carbone, D.P.; Shilo, K.; Giri, D.K.; et al. PDL1 Regulation by p53 via miR-34. J. Natl. Cancer Inst. 2016, 108, djv303. [CrossRef]

99. Xu, Y.; Wu, Y.; Zhang, S.; Ma, P.; Jin, X.; Wang, Z.; Yao, M.; Zhang, E.; Tao, B.; Qin, Y.; et al. A Tumor-Specific Super-Enhancer Drives Immune Evasion by Guiding Synchronous Expression of PD-L1 and PD-L2. Cell Rep. 2019, 29, 3435-3447.e4. [CrossRef]

100. Zaidi, M.R. The Interferon-Gamma Paradox in Cancer. J. Interferon Cytokine Res. 2019, 39, 30-38. [CrossRef]

101. Zaretsky, J.M.; Garcia-Diaz, A.; Shin, D.S.; Escuin-Ordinas, H.; Hugo, W.; Hu-Lieskovan, S.; Torrejon, D.Y.; Abril-Rodriguez, G.; Sandoval, S.; Barthly, L.; et al. Mutations Associated with Acquired Resistance to PD-1 Blockade in Melanoma. N. Engl. J. Med. 2016, 375, 819-829. [CrossRef] [PubMed]

102. Garcia-Diaz, A.; Shin, D.S.; Moreno, B.H.; Saco, J.; Escuin-Ordinas, H.; Rodriguez, G.A.; Zaretsky, J.M.; Sun, L.; Hugo, W.; Wang, X.; et al. Interferon Receptor Signaling Pathways Regulating PD-L1 and PD-L2 Expression. Cell Rep. 2017, 19, 1189-1201. [CrossRef] [PubMed]

103. Gowrishankar, K.; Gunatilake, D.; Gallagher, S.J.; Tiffen, J.; Rizos, H.; Hersey, P. Inducible but not constitutive expression of PD-L1 in human melanoma cells is dependent on activation of NF-kappaB. PLoS ONE 2015, 10, e0123410. [CrossRef] [PubMed]

104. Williams, J.B.; Li, S.; Higgs, E.F.; Cabanov, A.; Wang, X.; Huang, H.; Gajewski, T.F. Tumor heterogeneity and clonal cooperation influence the immune selection of IFN-gamma-signaling mutant cancer cells. Nat. Commun. 2020, 11, 602. [CrossRef] [PubMed]

105. Madore, J.; Strbenac, D.; Vilain, R.; Menzies, A.M.; Yang, J.Y.; Thompson, J.F.; Long, G.V.; Mann, G.J.; Scolyer, R.A.; Wilmott, J.S. PD-L1 Negative Status is Associated with Lower Mutation Burden, Differential Expression of Immune-Related Genes, and Worse Survival in Stage III Melanoma. Clin. Cancer Res. 2016, 22, 3915-3923. [CrossRef] [PubMed]

106. Chatterjee, A.; Rodger, E.J.; Ahn, A.; Stockwell, P.A.; Parry, M.; Motwani, J.; Gallagher, S.J.; Shklovskaya, E.; Tiffen, J.; Eccles, M.R.; et al. Marked Global DNA Hypomethylation Is Associated with Constitutive PD-L1 Expression in Melanoma. iScience 2018, 4, 312-325. [CrossRef]

107. Gallagher, S.J.; Mijatov, B.; Gunatilake, D.; Gowrishankar, K.; Tiffen, J.; James, W.; Jin, L.; Pupo, G.; Cullinane, C.; McArthur, G.A.; et al. Control of NF-kB activity in human melanoma by bromodomain and extra-terminal protein inhibitor I-BET151. Pigment. Cell Melanoma Res. 2014, 27, 1126-1137. [CrossRef] 
108. Yee, D.; Shah, K.M.; Coles, M.C.; Sharp, T.V.; Lagos, D. MicroRNA-155 induction via TNF-alpha and IFN-gamma suppresses expression of programmed death ligand-1 (PD-L1) in human primary cells. J. Biol. Chem. 2017, 292, 20683-20693. [CrossRef]

109. Audrito, V.; Serra, S.; Stingi, A.; Orso, F.; Gaudino, F.; Bologna, C.; Neri, F.; Garaffo, G.; Nassini, R.; Baroni, G.; et al. PD-L1 up-regulation in melanoma increases disease aggressiveness and is mediated through miR-17-5p. Oncotarget 2017, 8, 15894-15911. [CrossRef]

110. Boldrini, L.; Giordano, M.; Niccoli, C.; Melfi, F.; Lucchi, M.; Mussi, A.; Fontanini, G. Role of microRNA-33a in regulating the expression of PD-1 in lung adenocarcinoma. Cancer Cell Int. 2017, 17, 105. [CrossRef]

111. Dong, P.; Xiong, Y.; Yu, J.; Chen, L.; Tao, T.; Yi, S.; Hanley, S.J.B.; Yue, J.; Watari, H.; Sakuragi, N. Control of PD-L1 expression by miR-140/142/340/383 and oncogenic activation of the OCT4-miR-18a pathway in cervical cancer. Oncogene 2018, 37, 5257-5268. [CrossRef] [PubMed]

112. Zhu, J.; Chen, L.; Zou, L.; Yang, P.; Wu, R.; Mao, Y.; Zhou, H.; Li, R.; Wang, K.; Wang, W.; et al. MiR-20b, -21, and -130b inhibit PTEN expression resulting in B7-H1 over-expression in advanced colorectal cancer. Hum. Immunol. 2014, 75, 348-353. [CrossRef] [PubMed]

113. Wang, N.; Zhang, T. Downregulation of MicroRNA-135 Promotes Sensitivity of Non-Small Cell Lung Cancer to Gefitinib by Targeting TRIM16. Oncol. Res. 2018, 26, 1005-1014. [CrossRef] [PubMed]

114. Kao, S.C.; Cheng, Y.Y.; Williams, M.; Kirschner, M.B.; Madore, J.; Lum, T.; Sarun, K.H.; Linton, A.; McCaughan, B.; Klebe, S.; et al. Tumor Suppressor microRNAs Contribute to the Regulation of PD-L1 Expression in Malignant Pleural Mesothelioma. J. Thorac. Oncol. 2017, 12, 1421-1433. [CrossRef] [PubMed]

115. Tao, Z.; Xu, S.; Ruan, H.; Wang, T.; Song, W.; Qian, L.; Chen, K. MiR-195/-16 Family Enhances Radiotherapy via $\mathrm{T}$ Cell Activation in the Tumor Microenvironment by Blocking the PD-L1 Immune Checkpoint. Cell Physiol. Biochem. 2018, 48, 801-814. [CrossRef]

116. Cioffi, M.; Trabulo, S.M.; Vallespinos, M.; Raj, D.; Kheir, T.B.; Lin, M.L.; Begum, J.; Baker, A.M.; Amgheib, A.; Saif, J.; et al. The miR-25-93-106b cluster regulates tumor metastasis and immune evasion via modulation of CXCL12 and PD-L1. Oncotarget 2017, 8, 21609-21625. [CrossRef]

117. Anastasiadou, E.; Stroopinsky, D.; Alimperti, S.; Jiao, A.L.; Pyzer, A.R.; Cippitelli, C.; Pepe, G.; Severa, M.; Rosenblatt, J.; Etna, M.P.; et al. Epstein-Barr virus-encoded EBNA2 alters immune checkpoint PD-L1 expression by downregulating miR-34a in B-cell lymphomas. Leukemia 2019, 33, 132-147. [CrossRef]

118. Zhao, L.; Yu, H.; Yi, S.; Peng, X.; Su, P.; Xiao, Z.; Liu, R.; Tang, A.; Li, X.; Liu, F.; et al. The tumor suppressor miR-138-5p targets PD-L1 in colorectal cancer. Oncotarget 2016, 7, 45370-45384. [CrossRef]

119. Jiang, W.; Li, T.; Wang, J.; Jiao, R.; Shi, X.; Huang, X.; Ji, G. miR-140-3p Suppresses Cell Growth And Induces Apoptosis In Colorectal Cancer By Targeting PD-L1. Onco Targets Ther. 2019, 12, 10275-10285. [CrossRef]

120. Xie, W.B.; Liang, L.H.; Wu, K.G.; Wang, L.X.; He, X.; Song, C.; Wang, Y.Q.; Li, Y.H. MiR-140 Expression Regulates Cell Proliferation and Targets PD-L1 in NSCLC. Cell. Physiol. Biochem. 2018, 46, 654-663. [CrossRef]

121. Jia, L.; Xi, Q.; Wang, H.; Zhang, Z.; Liu, H.; Cheng, Y.; Guo, X.; Zhang, J.; Zhang, Q.; Zhang, L.; et al. miR-142-5p regulates tumor cell PD-L1 expression and enhances anti-tumor immunity. Biochem. Biophys. Res. Commun. 2017, 488, 425-431. [CrossRef] [PubMed]

122. Wan, J.; Ling, X.; Peng, B.; Ding, G. miR-142-5p regulates CD4+ T cells in human non-small cell lung cancer through PD-L1 expression via the PTEN pathway. Oncol. Rep. 2018, 40, 272-282. [CrossRef] [PubMed]

123. Ashizawa, M.; Okayama, H.; Ishigame, T.; Thar Min, A.K.; Saito, K.; Ujiie, D.; Murakami, Y.; Kikuchi, T.; Nakayama, Y.; Noda, M.; et al. miRNA-148a-3p Regulates Immunosuppression in DNA Mismatch Repair-Deficient Colorectal Cancer by Targeting PD-L1. Mol. Cancer Res. 2019, 17, 1403-1413. [PubMed]

124. Xie, G.; Li, W.; Li, R.; Wu, K.; Zhao, E.; Zhang, Y.; Zhang, P.; Shi, L.; Wang, D.; Yin, Y.; et al. Helicobacter Pylori Promote B7-H1 Expression by Suppressing miR-152 and miR-200b in Gastric Cancer Cells. PLoS ONE 2017, 12, e0168822. [CrossRef]

125. Chen, X.Y.; Zhang, J.; Hou, L.D.; Zhang, R.; Chen, W.; Fan, H.N.; Huang, Y.X.; Liu, H.; Zhu, J.S. Upregulation of PD-L1 predicts poor prognosis and is associated with miR-191-5p dysregulation in colon adenocarcinoma. Int. J. Immunopathol. Pharmacol. 2018, 32, 2058738418790318. [CrossRef]

126. He, B.; Yan, F.; Wu, C. Overexpressed miR-195 attenuated immune escape of diffuse large B-cell lymphoma by targeting PD-L1. Biomed. Pharmacother. 2018, 98, 95-101. [CrossRef]

127. Zhou, W.Y.; Zhang, M.M.; Liu, C.; Kang, Y.; Wang, J.O.; Yang, X.H. Long noncoding RNA LINC00473 drives the progression of pancreatic cancer via upregulating programmed death-ligand 1 by sponging microRNA-195-5p. J. Cell. Physiol. 2019, 234, 23176-23189. [CrossRef] 
128. Fujita, Y.; Yagishita, S.; Hagiwara, K.; Yoshioka, Y.; Kosaka, N.; Takeshita, F.; Fujiwara, T.; Tsuta, K.; Nokihara, H.; Tamura, T.; et al. The clinical relevance of the miR-197/CKS1B/STAT3-mediated PD-L1 network in chemoresistant non-small-cell lung cancer. Mol. Ther. 2015, 23, 717-727. [CrossRef]

129. Sun, C.; Lan, P.; Han, Q.; Huang, M.; Zhang, Z.; Xu, G.; Song, J.; Wang, J.; Wei, H.; Zhang, J.; et al. Oncofetal gene SALL4 reactivation by hepatitis B virus counteracts miR-200c in PD-L1-induced T cell exhaustion. Nat. Commun. 2018, 9, 1241. [CrossRef]

130. Noman, M.Z.; Janji, B.; Abdou, A.; Hasmim, M.; Terry, S.; Tan, T.Z.; Mami-Chouaib, F.; Thiery, J.P.; Chouaib, S. The immune checkpoint ligand PD-L1 is upregulated in EMT-activated human breast cancer cells by a mechanism involving ZEB-1 and miR-200. Oncoimmunology 2017, 6, e1263412. [CrossRef]

131. Pyzer, A.R.; Stroopinsky, D.; Rosenblatt, J.; Anastasiadou, E.; Rajabi, H.; Washington, A.; Tagde, A.; Chu, J.H.; Coll, M.; Jiao, A.L.; et al. MUC1 inhibition leads to decrease in PD-L1 levels via upregulation of miRNAs. Leukemia 2017, 31, 2780-2790. [CrossRef] [PubMed]

132. Miao, S.; Mao, X.; Zhao, S.; Song, K.; Xiang, C.; Lv, Y.; Jiang, H.; Wang, L.; Li, B.; Yang, X.; et al. miR-217 inhibits laryngeal cancer metastasis by repressing AEG-1 and PD-L1 expression. Oncotarget 2017, 8, 62143-62153. [CrossRef] [PubMed]

133. Wu, Q.; Zhao, Y.; Sun, Y.; Yan, X.; Wang, P. miR-375 inhibits IFN-gamma-induced programmed death 1 ligand 1 surface expression in head and neck squamous cell carcinoma cells by blocking JAK2/STAT1 signaling. Oncol. Rep. 2018, 39, 1461-1468. [PubMed]

134. Xu, S.; Tao, Z.; Hai, B.; Liang, H.; Shi, Y.; Wang, T.; Song, W.; Chen, Y.; OuYang, J.; Chen, J.; et al. miR-424(322) reverses chemoresistance via T-cell immune response activation by blocking the PD-L1 immune checkpoint. Nat. Commun. 2016, 7, 11406. [CrossRef]

135. Qu, F.; Ye, J.; Pan, X.; Wang, J.; Gan, S.; Chu, C.; Chu, J.; Zhang, X.; Liu, M.; He, H.; et al. MicroRNA-497-5p down-regulation increases PD-L1 expression in clear cell renal cell carcinoma. J. Drug Target. 2019, 27, 67-74. [CrossRef]

136. Nong, K.; Zhang, D.; Chen, C.; Yang, Y.; Yang, Y.; Liu, S.; Cai, H. MicroRNA-519 inhibits hypoxia-induced tumorigenesis of pancreatic cancer by regulating immune checkpoint PD-L1. Oncol. Lett. 2020, 19, 1427-1433. [CrossRef]

137. Wang, W.; Li, F.; Mao, Y.; Zhou, H.; Sun, J.; Li, R.; Liu, C.; Chen, W.; Hua, D.; Zhang, X. A miR-570 binding site polymorphism in the B7-H1 gene is associated with the risk of gastric adenocarcinoma. Hum. Genet. 2013, 132, 641-648. [CrossRef]

138. Gao, L.; Guo, Q.; Li, X.; Yang, X.; Ni, H.; Wang, T.; Zhao, Q.; Liu, H.; Xing, Y.; Xi, T.; et al. MiR-873/PD-L1 axis regulates the stemness of breast cancer cells. EBioMedicine 2019, 41, 395-407. [CrossRef]

139. Li, D.; Wang, X.; Yang, M.; Kan, Q.; Duan, Z. miR3609 sensitizes breast cancer cells to adriamycin by blocking the programmed death-ligand 1 immune checkpoint. Exp. Cell Res. 2019, 380, 20-28. [CrossRef]

140. Tang, D.; Zhao, D.; Wu, Y.; Yao, R.; Zhou, L.; Lu, L.; Gao, W.; Sun, Y. The miR-3127-5p/p-STAT3 axis up-regulates PD-L1 inducing chemoresistance in non-small-cell lung cancer. J. Cell. Mol. Med. 2018, 22, 3847-3856. [CrossRef]

141. Hsu, J.M.; Xia, W.; Hsu, Y.H.; Chan, L.C.; Yu, W.H.; Cha, J.H.; Chen, C.T.; Liao, H.W.; Kuo, C.W.; Khoo, K.H.; et al. STT3-dependent PD-L1 accumulation on cancer stem cells promotes immune evasion. Nat. Commun. 2018, 9, 1908. [CrossRef] [PubMed]

142. Li, C.W.; Lim, S.O.; Xia, W.; Lee, H.H.; Chan, L.C.; Kuo, C.W.; Khoo, K.H.; Chang, S.S.; Cha, J.H.; Kim, T.; et al. Glycosylation and stabilization of programmed death ligand-1 suppresses T-cell activity. Nat. Commun. 2016, 7, 12632. [CrossRef] [PubMed]

143. Li, C.W.; Lim, S.O.; Chung, E.M.; Kim, Y.S.; Park, A.H.; Yao, J.; Cha, J.H.; Xia, W.; Chan, L.C.; Kim, T.; et al. Eradication of Triple-Negative Breast Cancer Cells by Targeting Glycosylated PD-L1. Cancer Cell 2018, 33, 187-201.e10. [CrossRef] [PubMed]

144. Hsu, J.M.; Li, C.W.; Lai, Y.J.; Hung, M.C. Posttranslational Modifications of PD-L1 and Their Applications in Cancer Therapy. Cancer Res. 2018, 78, 6349-6353. [CrossRef]

145. Cha, J.H.; Yang, W.H.; Xia, W.; Wei, Y.; Chan, L.C.; Lim, S.O.; Li, C.W.; Kim, T.; Chang, S.S.; Lee, H.H.; et al. Metformin Promotes Antitumor Immunity via Endoplasmic-Reticulum-Associated Degradation of PD-L1. Mol. Cell 2018, 71, 606-620.e7. [CrossRef] 
146. Sun, L.; Li, C.W.; Chung, E.M.; Yang, R.; Kim, Y.S.; Park, A.H.; Lai, Y.J.; Yang, Y.; Wang, Y.H.; Liu, J.; et al. Targeting Glycosylated PD-1 Induces Potent Antitumor Immunity. Cancer Res. 2020, 80, 2298-2310.

147. Morales-Betanzos, C.A.; Lee, H.; Gonzalez Ericsson, P.I.; Balko, J.M.; Johnson, D.B.; Zimmerman, L.J.; Liebler, D.C. Quantitative Mass Spectrometry Analysis of PD-L1 Protein Expression, N-glycosylation and Expression Stoichiometry with PD-1 and PD-L2 in Human Melanoma. Mol. Cell. Proteomics 2017, 16, 1705-1717. [CrossRef]

148. Lim, S.O.; Li, C.W.; Xia, W.; Cha, J.H.; Chan, L.C.; Wu, Y.; Chang, S.S.; Lin, W.C.; Hsu, J.M.; Hsu, Y.H.; et al. Deubiquitination and Stabilization of PD-L1 by CSN5. Cancer Cell 2016, 30, 925-939. [CrossRef]

149. Mezzadra, R.; Sun, C.; Jae, L.T.; Gomez-Eerland, R.; de Vries, E.; Wu, W.; Logtenberg, M.E.W.; Slagter, M.; Rozeman, E.A.; Hofland, I.; et al. Identification of CMTM6 and CMTM4 as PD-L1 protein regulators. Nature 2017, 549, 106-110. [CrossRef]

150. Burr, M.L.; Sparbier, C.E.; Chan, Y.C.; Williamson, J.C.; Woods, K.; Beavis, P.A.; Lam, E.Y.N.; Henderson, M.A.; Bell, C.C.; Stolzenburg, S.; et al. CMTM6 maintains the expression of PD-L1 and regulates anti-tumour immunity. Nature 2017, 549, 101-105. [CrossRef]

151. Zhang, J.; Bu, X.; Wang, H.; Zhu, Y.; Geng, Y.; Nihira, N.T.; Tan, Y.; Ci, Y.; Wu, F.; Dai, X.; et al. Cyclin D-CDK4 kinase destabilizes PD-L1 via cullin 3-SPOP to control cancer immune surveillance. Nature 2018, 553, 91-95. [CrossRef] [PubMed]

152. Liang, J.; Wang, L.; Wang, C.; Shen, J.; Su, B.; Marisetty, A.L.; Fang, D.; Kassab, C.; Jeong, K.J.; Zhao, W.; et al. Verteporfin Inhibits PD-L1 through Autophagy and the STAT1-IRF1-TRIM28 Signaling Axis, Exerting Antitumor Efficacy. Cancer Immunol. Res. 2020, 8, 952-965. [CrossRef] [PubMed]

153. Zhou, J.; Mahoney, K.M.; Giobbie-Hurder, A.; Zhao, F.; Lee, S.; Liao, X.; Rodig, S.; Li, J.; Wu, X.; Butterfield, L.H.; et al. Soluble PD-L1 as a Biomarker in Malignant Melanoma Treated with Checkpoint Blockade. Cancer Immunol. Res. 2017, 5, 480-492. [CrossRef]

154. Mahoney, K.M.; Shukla, S.A.; Patsoukis, N.; Chaudhri, A.; Browne, E.P.; Arazi, A.; Eisenhaure, T.M.; Pendergraft, W.F., 3rd; Hua, P.; Pham, H.C.; et al. A secreted PD-L1 splice variant that covalently dimerizes and mediates immunosuppression. Cancer Immunol. Immunother. 2019, 68, 421-432. [CrossRef] [PubMed]

155. Fan, Y.; Che, X.; Qu, J.; Hou, K.; Wen, T.; Li, Z.; Li, C.; Wang, S.; Xu, L.; Liu, Y.; et al. Exosomal PD-L1 Retains Immunosuppressive Activity and is Associated with Gastric Cancer Prognosis. Ann. Surg. Oncol. 2019, 26, 3745-3755. [CrossRef]

156. Cordonnier, M.; Nardin, C.; Chanteloup, G.; Derangere, V.; Algros, M.P.; Arnould, L.; Garrido, C.; Aubin, F.; Gobbo, J. Tracking the evolution of circulating exosomal-PD-L1 to monitor melanoma patients. J. Extracell. Vesicles 2020, 9, 1710899. [CrossRef]

157. Zhao, F.; Evans, K.; Xiao, C.; DeVito, N.; Theivanthiran, B.; Holtzhausen, A.; Siska, P.J.; Blobe, G.C.; Hanks, B.A. Stromal Fibroblasts Mediate Anti-PD-1 Resistance via MMP-9 and Dictate TGFbeta Inhibitor Sequencing in Melanoma. Cancer Immunol. Res. 2018, 6, 1459-1471. [CrossRef]

158. Frigola, X.; Inman, B.A.; Lohse, C.M.; Krco, C.J.; Cheville, J.C.; Thompson, R.H.; Leibovich, B.; Blute, M.L.; Dong, H.; Kwon, E.D. Identification of a soluble form of B7-H1 that retains immunosuppressive activity and is associated with aggressive renal cell carcinoma. Clin. Cancer Res. 2011, 17, 1915-1923. [CrossRef]

159. Zhang, J.; Gao, J.; Li, Y.; Nie, J.; Dai, L.; Hu, W.; Chen, X.; Han, J.; Ma, X.; Tian, G.; et al. Circulating PD-L1 in NSCLC patients and the correlation between the level of PD-L1 expression and the clinical characteristics. Thorac. Cancer 2015, 6, 534-538. [CrossRef]

160. Rossille, D.; Gressier, M.; Damotte, D.; Maucort-Boulch, D.; Pangault, C.; Semana, G.; Le Gouill, S.; Haioun, C.; Tarte, K.; Lamy, T.; et al. High level of soluble programmed cell death ligand 1 in blood impacts overall survival in aggressive diffuse large B-Cell lymphoma: Results from a French multicenter clinical trial. Leukemia 2014, 28, 2367-2375. [CrossRef]

161. Ugurel, S.; Schadendorf, D.; Horny, K.; Sucker, A.; Schramm, S.; Utikal, J.; Pfohler, C.; Herbst, R.; Schilling, B.; Blank, C.; et al. Elevated baseline serum PD-1 or PD-L1 predicts poor outcome of PD-1 inhibition therapy in metastatic melanoma. Ann. Oncol. 2020, 31, 144-152. [CrossRef] [PubMed]

162. Taube, J.M.; Klein, A.; Brahmer, J.R.; Xu, H.; Pan, X.; Kim, J.H.; Chen, L.; Pardoll, D.M.; Topalian, S.L.; Anders, R.A. Association of PD-1, PD-1 ligands, and other features of the tumor immune microenvironment with response to anti-PD-1 therapy. Clin. Cancer Res. 2014, 20, 5064-5074. [CrossRef] [PubMed] 
163. Vilain, R.E.; Menzies, A.M.; Wilmott, J.S.; Kakavand, H.; Madore, J.; Guminski, A.; Liniker, E.; Kong, B.Y.; Cooper, A.J.; Howle, J.R.; et al. Dynamic Changes in PD-L1 Expression and Immune Infiltrates Early During Treatment Predict Response to PD-1 Blockade in Melanoma. Clin. Cancer Res. 2017, 23, 5024-5033. [CrossRef]

164. Noguchi, T.; Ward, J.P.; Gubin, M.M.; Arthur, C.D.; Lee, S.H.; Hundal, J.; Selby, M.J.; Graziano, R.F.; Mardis, E.R.; Korman, A.J.; et al. Temporally Distinct PD-L1 Expression by Tumor and Host Cells Contributes to Immune Escape. Cancer Immunol. Res. 2017, 5, 106-117. [CrossRef] [PubMed]

165. Huang, A.C.; Orlowski, R.J.; Xu, X.; Mick, R.; George, S.M.; Yan, P.K.; Manne, S.; Kraya, A.A.; Wubbenhorst, B.; Dorfman, L.; et al. A single dose of neoadjuvant PD-1 blockade predicts clinical outcomes in resectable melanoma. Nat. Med. 2019, 25, 454-461. [CrossRef] [PubMed]

166. Yost, K.E.; Satpathy, A.T.; Wells, D.K.; Qi, Y.; Wang, C.; Kageyama, R.; McNamara, K.L.; Granja, J.M.; Sarin, K.Y.; Brown, R.A.; et al. Clonal replacement of tumor-specific T cells following PD-1 blockade. Nat. Med. 2019, 25, 1251-1259. [CrossRef]

167. Chen, P.L.; Roh, W.; Reuben, A.; Cooper, Z.A.; Spencer, C.N.; Prieto, P.A.; Miller, J.P.; Bassett, R.L.; Gopalakrishnan, V.; Wani, K.; et al. Analysis of Immune Signatures in Longitudinal Tumor Samples Yields Insight into Biomarkers of Response and Mechanisms of Resistance to Immune Checkpoint Blockade. Cancer Discov. 2016, 6, 827-837. [CrossRef]

168. Hugo, W.; Zaretsky, J.M.; Sun, L.; Song, C.; Moreno, B.H.; Hu-Lieskovan, S.; Berent-Maoz, B.; Pang, J.; Chmielowski, B.; Cherry, G.; et al. Genomic and Transcriptomic Features of Response to Anti-PD-1 Therapy in Metastatic Melanoma. Cell 2016, 165, 35-44. [CrossRef]

169. Muller, J.; Krijgsman, O.; Tsoi, J.; Robert, L.; Hugo, W.; Song, C.; Kong, X.; Possik, P.A.; Cornelissen-Steijger, P.D.; Geukes Foppen, M.H.; et al. Low MITF/AXL ratio predicts early resistance to multiple targeted drugs in melanoma. Nat. Commun. 2014, 5, 5712. [CrossRef]

170. Mariathasan, S.; Turley, S.J.; Nickles, D.; Castiglioni, A.; Yuen, K.; Wang, Y.; Kadel, E.E., III; Koeppen, H.; Astarita, J.L.; Cubas, R.; et al. TGFbeta attenuates tumour response to PD-L1 blockade by contributing to exclusion of T cells. Nature 2018, 554, 544-548. [CrossRef]

171. Tauriello, D.V.F.; Palomo-Ponce, S.; Stork, D.; Berenguer-Llergo, A.; Badia-Ramentol, J.; Iglesias, M.; Sevillano, M.; Ibiza, S.; Canellas, A.; Hernando-Momblona, X.; et al. TGFbeta drives immune evasion in genetically reconstituted colon cancer metastasis. Nature 2018, 554, 538-543. [CrossRef] [PubMed]

172. Kang, Y.; Massague, J. Epithelial-mesenchymal transitions: Twist in development and metastasis. Cell 2004, 118, 277-279. [CrossRef] [PubMed]

173. Ruan, Z.; Liang, M.; Lai, M.; Shang, L.; Deng, X.; Su, X. KYA1797K down-regulates PD-L1 in colon cancer stem cells to block immune evasion by suppressing the beta-catenin/STT3 signaling pathway. Int. Immunopharmacol. 2020, 78, 106003. [CrossRef] [PubMed]

174. Tsukita, Y.; Fujino, N.; Miyauchi, E.; Saito, R.; Fujishima, F.; Itakura, K.; Kyogoku, Y.; Okutomo, K.; Yamada, M.; Okazaki, T.; et al. Axl kinase drives immune checkpoint and chemokine signalling pathways in lung adenocarcinomas. Mol. Cancer 2019, 18, 24. [CrossRef]

175. Skinner, H.D.; Giri, U.; Yang, L.P.; Kumar, M.; Liu, Y.; Story, M.D.; Pickering, C.R.; Byers, L.A.; Williams, M.D.; Wang, J.; et al. Integrative Analysis Identifies a Novel AXL-PI3 Kinase-PD-L1 Signaling Axis Associated with Radiation Resistance in Head and Neck Cancer. Clin. Cancer Res. 2017, 23, 2713-2722. [CrossRef]

176. Ott, P.A.; Bang, Y.J.; Piha-Paul, S.A.; Razak, A.R.A.; Bennouna, J.; Soria, J.C.; Rugo, H.S.; Cohen, R.B.; O'Neil, B.H.; Mehnert, J.M.; et al. T-Cell-Inflamed Gene-Expression Profile, Programmed Death Ligand 1 Expression, and Tumor Mutational Burden Predict Efficacy in Patients Treated With Pembrolizumab Across 20 Cancers: KEYNOTE-028. J. Clin. Oncol. 2019, 37, 318-327. [CrossRef]

177. Thorsson, V.; Gibbs, D.L.; Brown, S.D.; Wolf, D.; Bortone, D.S.; Ou Yang, T.H.; Porta-Pardo, E.; Gao, G.F.; Plaisier, C.L.; Eddy, J.A.; et al. The Immune Landscape of Cancer. Immunity 2018, 48, 812-830.e14. [CrossRef]

178. Saltz, J.; Gupta, R.; Hou, L.; Kurc, T.; Singh, P.; Nguyen, V.; Samaras, D.; Shroyer, K.R.; Zhao, T.; Batiste, R.; et al. Spatial Organization and Molecular Correlation of Tumor-Infiltrating Lymphocytes Using Deep Learning on Pathology Images. Cell Rep. 2018, 23, 181-193.e7. [CrossRef] 
179. Kleffel, S.; Posch, C.; Barthel, S.R.; Mueller, H.; Schlapbach, C.; Guenova, E.; Elco, C.P.; Lee, N.; Juneja, V.R.; Zhan, Q.; et al. Melanoma Cell-Intrinsic PD-1 Receptor Functions Promote Tumor Growth. Cell 2015, 162, 1242-1256. [CrossRef]

180. Kumagai, S.; Togashi, Y.; Kamada, T.; Sugiyama, E.; Nishinakamura, H.; Takeuchi, Y.; Vitaly, K.; Itahashi, K.; Maeda, Y.; Matsui, S.; et al. The PD-1 expression balance between effector and regulatory T cells predicts the clinical efficacy of PD-1 blockade therapies. Nat. Immunol. 2020. [CrossRef]

(c)

(C) 2020 by the authors. Licensee MDPI, Basel, Switzerland. This article is an open access article distributed under the terms and conditions of the Creative Commons Attribution (CC BY) license (http://creativecommons.org/licenses/by/4.0/). 